\title{
Meraklı Minik Dergisinin Değerler Eğitimi Açısından Değerlendirilmesi*
}

\section{The Evaluation of Preschool Children's Magazine the "Meraklı Minik" in Terms of Values Education**}

\author{
Ensar YILDIZ, Sorumlu Yazar, Araştırma Görevlisi. \\ Sivas Cumhuriyet Üniversitesi, Eğitim Fakültesi, Sivas / Türkiye \\ ensaryildiz@outlook.com.tr \\ https://orcid.org/0000-0003-3741-1121
}

Kübra EMIN, Yüksek Lisans Öğrencisi

Sivas Cumhuriyet Üniversitesi, Eğitim Fakültesi, Sivas / Türkiye

kubragemin@gmail.com

https://orcid.org/0000-0002-4852-8459

Şuheda BAYRAK, Yüksek Lisans Öğrencisi

Sivas Cumhuriyet Üniversitesi, Eğitim Fakültesi, Sivas / Türkiye

suheda2011@gmail.com

https://orcid.org/0000-0002-0068-3871

Büşra YIKILMAZ BARAN, Yüksek Lisans Öğrencisi

Sivas Cumhuriyet Üniversitesi, Eğitim Fakültesi, Sivas / Türkiye

busrayikilmazl@gmail.com

https://orcid.org/0000-0003-3762-985X

ISSN: 1303-880X

e-ISSN: 2667-7504

http://ded.dem.org.tr

Makale Türü / Article Type:

Araştırma Makalesi / Research Article

Geliş Tarihi / Received Date: 07.05.2021

Kabul Tarihi / Accepted Date: 27.09. 2021

Yayın Tarihi / Published Date: 25.12.202 1

Tr/En: $\operatorname{Tr}$

Intihal / Plagiarism: Bu makale, en az iki hakem tarafindan incelendi ve intihal içermediği teyit edildi. / This article has been reviewed by at least two referees and scanned via a plagiarism software.
Atıf/Citation: Y1ldı, E., Emin, K., Bayrak, Ş., Y1kılmaz Baran, B. (2021). Meraklı Minik Dergisinin değerler eğitimi açısından değerlendirilmesi. Değerler Ĕgitimi Dergisi, 19 (42), s.113-151

https://doi.org/10.34234/ded.934064

* Bu çalışma 24-26 Aralık 2020 tarihinde Karabük’te gerçekleştirilen 4. Uluslaraası Eğitim ve Değerler Sempozyumu (Online)'nda sözlü bildiri olarak sunulmuştur.

** This study was presented as an oral presentation at the 4th International Education and Values Symposium (Online) held in Karabuk on 24-26 December 2020. 
Öz: Bu çalışmada, "Meraklı Minik" dergisinin değerler eğitimi açısından değerlendirilmesi amaçlanmıştır. Nitel paradigmaya uygun yürütülen çalışmanın örneklem seçiminde amaçlı örneklem yöntemlerinden ölçüt örnekleme kullanılmıştır. Çalışmada iki farklı veri kaynağından yararlanılmıştır. Veri kaynaklarını "Meraklı Minik" dergisinin 2007-2020 y1lları arasındaki 156 sayı ve okul öncesi dönem çocuğu olan 10 ebeveyn oluşturmaktadır. Veri toplama aracı olarak "Meraklı Minik" dergisi için Millî Eğitim Bakanlığı tarafından 2010 yılında yayımlanan 53 sayılı ilk ders genelgesinden yararlanarak araştırmacılar tarafindan geliştirilen "Değer Sınıflama Formu" kullanılarak doküman incelemesi ve ebeveynler için araştırmacılar tarafından geliştirilen yarı yapılandırılmış görüşme formu ile görüsşme tekniği kullanılmıştır. Toplanan verilerin analizinde içerik analizi tekniği kullanılmıştır. Çalışmada "Meraklı Minik" dergisinde toplam 26 farklı değere yer verildiği saptanmıştır. Çalışmada "Meraklı Minik" dergisinde en fazla yardımlaşma dayanışma ve estetik duyguların geliştirilmesi değerlerine rastlanırken en az adil olma, alçak gönüllülük, misafirperverlik, nazik olma, fedakârlık, vatanseverlik, değerine yer verildiği görülmüştür. Araştırma sonuçlarına göre okul öncesi çocuklarının dönem özelliği dikkate aldığında değerler eğitimi açısından derginin içeriğinin zenginleştirilmesi sonucuna ulaşılmıştır. "Meraklı Minik" dergisinin, hedef kitlesi olan okul öncesi dönem çocuklarının gelişim özelliklerini dikkate alarak değer kavramlarına daha fazla yer vermesi önerilmektedir.

Anahtar Kelimeler: Değerler Eğitimi, Ebeveyn Görüşü, Okul Öncesi Dönem, "Meraklı Minik" Dergisi.

\section{\&}

Abstract: This study aimed to evaluate "Merakl1 Minik" magazine from values education perspective. Criterion sampling, one of the purposeful sampling methods, was used in the selection of the sample of the study, which was carried out in accordance with the qualitative paradigm. The study made use of two different types of data sources. The data are consisted of 156 issues of the "Meraklı Minik" magazine between 2007-2020 and 10 parents with preschool children. As a data collection tool, The Value Classification Form" was used for document analysis of the magazine that developed by the researchers based on The Circular Letter numbered 53 issued by the Ministry of National Education in 2010, semi-structured interview form was also used as a tool to reveal the views of parents. A total of 26 different values were included in the magazine 
"Merakl1 Minik". This study indicated that "Merakl1 Minik" magazine mostly includes values of solidarity, solidarity and aesthetic feelings, while the least values of fairness, humility, hospitality, kindness, sacrifice, patriotism are included. It was revealed that the magazine should give more place to the concepts of values besides scientific knowledge. In the light of these results, it is recommended that "Meraklı Minik", of which the target audience is preschool children, should give more place to the concepts of values with taking into account the developmental characteristics of preschool children.

Keywords: Preschool Period, Values Education, Views of Parents, Magazine of Meraklı Minik.

(The Extended Abstract is at the end of the article)

\section{Giriş}

Değer, toplumda kıymetli görülen ve olması arzulanan ilkeler ve kurallar olarak ifade edilebilir (Cooper, 2014; Sagiv, 2002). Değerler toplumun temelini oluştururken kişiler arası ilişkileri düzenleme ve bütünleşmeyi sağlaması yönüyle toplumsal yaşamın refah içinde sürdürülmesi için önem taşımaktadır (Tekinşen, 2019). Ayrıca değerler insanların toplumsal hayat içindeki önceliklerini ve bu önceliklerini gerçekleştirebilme yöntemleri konusunda insanlara yol göstermektedir (Akbaş, 2008). Değerler ve ahlaki prensipler toplumdan topluma farklılaşabilmektedir (Karademir ve Çelik, 2020).

Bireyin değerlerin neler olduğunu bilmesi, bu değerleri içselleştirerek yaşamını sürdürmesi ve değerlere yeni anlamlar kazandırması eğitim sistemiyle mümkün olmaktadır. Bu amaç doğrultusunda değer kazanımı eğitim sistemi içerisinde doğrudan öğretim yoluyla kazandırılmasının yanında örtük program aracılığıyla da kazandırılmaktadır (Kalaycı ve Güneş, 2014). Örtük program direkt olarak kazandırılan hedeflerin dışında daha çok duyuşsal alandaki hedefleri kazandırmada büyük önem taşımaktadır (Yurtseven, 2019). Silcock ve Duncan'a (2001) göre, çocuklara okulda öğretilecek değerlerin çocukların sosyal yaşamda karşılaştığı durumlar ile tutarlılık göstermesi gerekmektedir. Çocukların yaparak ve yaşayarak öğrenmesi öğrenmeyi kalıcı hale getirecek ve öğrenmeyi de kolaylaştıracaktır (Akman vd., 2015).

Eğitim kurumlarına başlamadan önce çocuklar, toplumsal kural ve değerleri, doğru ve yanlışı ayırt edebilmeyi ebeveynlerini gözleyerek ve onları taklit ederek öğrenmektedir (Meriç ve Özyürek, 2018). Değer eğitiminin gerçekleştiği 
ilk toplumsal kurumun aile olduğu düşünüldüğünde ebeveynlere büyük sorumluluk düşmektedir. Ailelerin çocuklara rol model olmanın yanı sıra sundukları çevre ve kaynaklar da değerler eğitiminde önem taşımaktadır (Yılmaz, 2018). $\mathrm{Bu}$ kaynaklardan çocuk dergileri değerlerin kazandırılmasında eğitim aracı niteliğinde görülmektedir (Tekinşen, 2019).

Çocuk dergileri çocuklara okuma alışkanlığını eğlenceli halde benimsetmeyi, bilimsel gelişmelerden, değerlerden, günlük hayat becerilerinden çocukları haberdar etmeyi amaçlayan süreli yayımlardır (Duran ve Dolaylar Özkul, 2018). Çocuk dergileri, çocukların; hayatı tanımasına, yaratıcılıklarının, dil ve sosyal becerilerinin gelişmesine, merak duygusunu gidermesinin yanı sıra yeni şeyleri merak etmesi için güdülenmelerine olanak sağlar (Yılar ve Celepoğlu, 2007). Dünya'da yayımlanan çocuk dergilerinden bazıları "Stor BOX", "GEO Mini", "PIPPO"dur. Ülkemizdeki çocuk dergilerine ise "TRT Çocuk Dergisi”, "Bilge Minik", "Yavru Kırlangıç" örnek verilebilir.

Alan yazını incelediğimizde çocuk dergileri ile ilgili uluslararası ve ulusal birçok çalışmaya rastlamak mümkündür (Ağan, 2019; Aksüt, 2021; Alabaş ve Kamer, 2016; Alabay, Can, Kandemir ve Güney, 2018; Chapman, Fairchild \& Morgan, 2014; Dedeoğlu vd., 2011; Gezmen, 2019; Kurniawan, Waluyo, Suwandi \& Setiawan, 2018; Jones \& Reid, 2009; Morrow \& Lesnick, 2001; Rea, 2018; Sarıkaya, 2018; Yıldırım, 2020).

Morrow ve Lesnick (2001), çocuk dergilerindeki eğitsel değerler isimli çalışmalarında, ögretmenlerin büyük çoğunluğunun sınıfında dergilerin yer aldığını ve ders içeriklerini hazırlarken sıklıkla bu dergilerden faydalandıklarını bulgulamıştır.

Yiğitbaşı (2014) çalışmasında, “TRT Çocuk Dergisi”nin 2012- 2013 yılları arasındaki 12 sayısını incelemiştir. Çalışmasının sonucunda derginin Dede Korkut, Karagöz gibi Türk milletinin geçmişinde yer alan millî kahramanların çocuklar tarafından tanıtılmasını sağladığını belirtmiştir.

Kurniawan, Waluyo, Suwandi ve Setiawan (2018) çalışmalarında, çocuk dergilerindeki öykülerde işlenen ahlâki değerleri incelemişlerdir. "Bobo Magazine" ve "Kompas Daily" dergilerinde yer alan öyküleri ele almışlardır. Çalışma sonucunda; itaat, arkadaşlık, dürüstlük, cesaret, disiplin, yaratıcılık ve şefkat değerlerine yer verildiğini bulgulamışlardır.

Rea (2018), Arjantin'in "Billiken" çocuk dergisinde eğitim, popüler yazın ve gelecekteki vatandaşlık konularını incelediği çalışmasında, derginin Arjantin toplumunun yazın, eğitim ve kültür şekillenmesinde rol oynadığını ve ülkedeki eğitim politikalarına yeni yaklaşımlar ve yenilikler kattığını belirtmiştir. 
Tekinşen (2019) “TRT Çocuk Dergisi”nde yer alan edebî metinlerin değerler eğitimi açısından incelenmesi isimli çalışmasında 2010-2016 yılları arasındaki yayımlanan 70 sayısını incelemiştir. Dergide değer eğitiminin doğrudan değil daha çok sezdirme ve keşfetme yoluyla verildiğini bulgulamıştır. Ayrıca dergide en çok yardımseverlik değerine yer verildiği en az ise iffetli olma, kanaatkârlık, özgürlük ve cesur olma değerlerinin yer aldığı sonucuna ulaşmıştır.

Türkiye'de yayımlanan çocuk dergilerinden bir tanesi de "Meraklı Minik" dergisidir. TÜBİTAK tarafından çıkarılan "Meraklı Minik" dergisi, 2007 Ocak ayı ile bilimi çocuklara sevdirerek tanıtma, çocuklardaki merak duygusunu geliştirme amacıyla 3-6 yaş çocukları için yayımlamaya başlamış olup halen yayım hayatını sürdürmektedir (Dedeoğlu vd., 2011). "Meraklı Minik” dergisi ile ilgili yapılmış yüksek lisans tezleri (Ağan, 2019; Yıldırım, 2020; Ergin, 2020; Pembegül, 2019) ve makale çalışmaları (Aksüt, 2021; Alabay vd., 2018; Ergin ve Özkan, 2021) mevcuttur. Çocuklara bilimi sevdirmeyi amaçlayan dergilerin de değerlere yer verme durumları incelenerek değerler eğitimine dikkat çekilmesi, değerler eğitimine verilen önemin artırılması açısından önem arz etmektedir. Ancak alan yazın incelendiğinde "Meraklı Minik" dergisini değerler eğitimi açısından inceleyen tek bir çalışma (Alabay ve diğ., 2018) bulunmaktadır.

Alabay ve diğ. (2018) çalışmalarında, "Meraklı Minik" dergisinin 2012-2016 yılları arasındaki sayıların UNESCO tarafindan belirlenen on iki evrensel değer açısından incelemiş̧tir. Araştırma sonucunda sevgi, sorumluluk ve işbirliği değerlerinin sıklıkla yer aldığı, barış dürüstlük ve alçak gönüllülük değerlerine ise hiç yer verilmediğine ulaşmışlardır.

Alan yazın incelendiğinde ülkemizde çok popüler bir dergi olan "Meraklı Minik" dergisinin değerler eğitimi açısından incelenmesine yönelik kapsamlı bir araştırma olmadığ 1 görülmektedir. Yapılmış olan araştırmada ise sadece dört yıllık bir sürenin incelendiği görülmektedir. Derginin 2007 Ocak ayı itibariyle günümüze kadar olan sayılarının incelenerek ülkemizde yaşanan çeşitli toplumsal olayların yansımaları doğrultusunda değerler eğitimi noktasındaki eğilimini belirlemek önemli görülmektedir. Ayrıca derginin hedef kitlesini oluşturan çocukların ebeveynlerinin değerler eğitimi ile ilgili dergiye yönelik beklentilerini ortaya koyan alan yazında bir çalışmaya rastlanılmamıştır. Bu doğrultuda çalışmamız 2007-2020 yılları arasındaki "Meraklı Minik" dergisinin tüm sayılarının değerler eğitimi boyutunda yıl bazında ele alması ve dergiye abone olan ebeveynlerin görüşlerini de incelemesi bakımından alandaki eksikliğin giderilmesi ve kullanılan örnekleme açısından da başka çalışmalara yol gösterici olacağ 
düşünülmektedir. Bu amaç doğrultusunda şu sorulara cevap aranmıştır:

1. "Meraklı Minik" dergisinde hangi değerler ne sıklıkla yer almaktadır?

2. "Meraklı Minik" dergisi değerler eğitimi açısından ebeveynlerin beklentilerini karşılamakta mıdır?

3. Ebeveynler, "Meraklı Minik" dergisinin çocuklarına hangi değerleri kazandırdığını düşünmektedir?

4. "Meraklı Minik" dergisinin değerler eğitimi konusunda daha da geliştirilmesi için ebeveynlerin önerileri nelerdir?

\section{Yöntem}

\section{Araştırmanın Modeli}

Çalışmada verilerin derinlemesine incelemek için veriler arasındaki ilişkileri ortaya koymayı hedefleyen nitel araştırma yöntemi kullanılmıştır. Nitel araştırma gözlem, görüşme, doküman incelemesi gibi veri toplama yöntemlerinin kullanıldığı, araştırılan durumu doğal ortamda ortaya koymayı amaçlayan bir yöntemdir (Yıldırım ve Şimşek, 2013).

\section{Veri Kaynakları}

Çalışmada "Meraklı Minik" dergisinin 2007-2020 yılları arasında çıkarılan aylık sayıları ve dergiye aboneliği devam eden okul öncesi dönem çocuğu olan 10 ebeveyn veri kaynaklarını oluşturmaktadır. Veri kaynakların biri olan ebeveynlerin seçiminde oluşturulmasında amaçlı örnekleme türlerinden ölçüt örnekleme kullanılmıştır. Meraklı Minik dergisine en az 6 ay aboneliği bulunan ve 3-6 yaş arası en az bir çocuğu olan ebeveynler kriter olarak seçilmiştir. Diğer veri kaynağı olan derginin ise çalışmaya başlanıldığı yıla kadar olan (2007-2020) tüm sayılarına ulaşılmıştır. Yanlış algılamayı ve sonuçların geçersizliğini en aza indirmek (Stake, 1995) için üçgenleme kullanılmıştır. Üçgenleme, doğruluğu artırmak için bir şeye çoklu bakış açısı ile bakmaktır (Neuman, 2014). 


\begin{tabular}{lllllll}
\hline \multicolumn{7}{l}{ Tablo 1: Katılımcı Demografik Bilgilerini Gösteren Tablo } \\
\hline \multirow{2}{*}{ KOD } & Yaş & $\begin{array}{l}\text { Eğitim } \\
\text { Düzeyi }\end{array}$ & $\begin{array}{l}\text { Aylık Gelir } \\
\text { Toplam }\end{array}$ & $\begin{array}{l}\text { Çocuk } \\
\text { Sayısı }\end{array}$ & $\begin{array}{l}\text { Çocuk/ların } \\
\text { Yaşları }\end{array}$ & Abonelik Yıl/Ay \\
\hline E1 & 38 & Doktora & $12.000 \mathrm{TL}$ & 2 & 5,5 yaş / 13 yaş & 2018 - Ocak \\
\hline E2 & 29 & Lisans & $7000 \mathrm{TL}$ & 2 & 3,5 yaş /1,5 yaş & $2019-$ Şubat \\
\hline E3 & 30 & Lisans & $5000 \mathrm{TL}$ & 1 & 4 yaş & $2019-$ Kasım \\
\hline E4 & 39 & Lisans & $9.000 \mathrm{TL}$ & 2 & 3.5 yaş/ 15 yaş & 2019 - Mart \\
\hline E5 & 30 & Lisans & $5.000 \mathrm{TL}$ & 1 & 5 yaş & 2019 - Mart \\
\hline E6 & 32 & Lisans & $2.900 \mathrm{TL}$ & 2 & 1 aylık/3,5 yaş & $2019-$ Nisan \\
\hline E7 & 29 & Lisans & $7000 \mathrm{TL}$ & 1 & 4 yaş & 2019 - Kasım \\
\hline E8 & 31 & Yüksek & $6500 \mathrm{TL}$ & 2 & 2 yaş/4yaş & 2019 - Aralık \\
\hline E9 & 35 & Önn lisans & $6000 \mathrm{TL}$ & 1 & 5 yaş & 2018 - Nisan \\
\hline E10 & 30 & Ön Lisans & $7100 \mathrm{TL}$ & 2 & 2,5 yaş/4,5yaş & 2019 - Ocak \\
\hline
\end{tabular}

Tablo 1'de ebeveynlere ait demografik bilgiler gösterilmiştir. Katılımcılardan E1'in eğitim durumunun doktora, E8'in yüksek lisans düzeyinde; E2, E3, E4, E5, E6 ve E7'nin lisans düzeyinde; E9 ve E10'un ön lisans düzeyinde olduğu, E1, E2, E4 ve E6'nın iki çocuğu, E3, E5 ve E7'nin bir çocuğu olduğu görülmektedir. Kat1lımc1lardan E2, E3, E4, E5, E6 ve E7' nin 2019 y1lında; E1'in 2018 y1lından beri abonelik süreçlerinin devam ettiği görülmektedir..

\section{Veri Toplama}

Çalışmada veri toplama sürecinde araştırmacılar tarafından geliştirilen "Değer Sınıflama Formu" ile doküman incelemesi ve "Yarı Yapılandırılmış Ebeveyn Görüşme Formu" görüşme tekniği kullanılarak veriler toplanmıştır.

Değer Sinıflama Formu. Araştırmacılar tarafindan "Millî Eğitim Bakanlığ1 tarafından 2010 yılında yayımlanan 53 numaralı ilk ders genelgesinde (MEB, 2010) belirtilen 27 değerlerden yararlanarak oluşturulan formda derginin yıl1, aylık teması, içerdiği değerlerin olduğu üç bölüm bulunmaktadır. Araştırmacılar tarafından geliştirilen form değerler eğitiminde çalışmaları olan iki alan uzmanına gönderilmiştir. Alan uzmanlarının görüşü doğrultusunda "değerin geçtiği cümle" bölümü eklenerek form dört bölümden oluşturulmuştur. "Değer Sınıflama Formu" kullanılarak Meraklı Minik Dergisi'nin yayım hayatına başladığı 2007 Ocak sayısından itibaren 2020 Aralık sayısına kadar olan toplam 156 sayısı incelenmiştir. Doküman incelemesi ile veri toplanmıştır. Kitap, dergi, gazete, e-içerikli belgeler gibi yazılı materyallerin incelendiği araştırma deseni doküman incelemesi olarak nitelendirilmektedir (Yıldırım ve Şimşek, 2013). 
Yar1 Yapılandırılmış Ebeveyn Görüşme Formu: Form iki bölümden oluşmaktadır. Araştırmacılar tarafından oluşturulan form değerler eğitiminde çalışmalar1 olan üç uzmana gönderilmiş ve uzman görüşü doğrultusunda "dergide değer kavramalının yer alma durumuna ilişkin görüşleriniz nelerdir?" sorusu eklenmiştir. Ardından üç ebeveyn ile soruların işlerliğini ve anlaşılırlığını sağlamak amacıyla görüşme yapılmıştır. Görüşme, sözlü iletişim yoluyla veri toplama yöntemlerindendir (Karasar, 2013). Başka bir ifadeyle, herhangi bir amaca yönelik olarak önceden belirlenmiş olarak, karşıdaki kişiye soru sorarak cevaplar alınan aktif bir sürece görüşme denir (Yıldırım ve Şimşek, 2013). Yapılan görüşmelerde sorulara uygun cevaplar alınmıştır. Ardından esas çalışmaya geçilmiştir. Yapılan görüşmeler ardından E1, E2, E3... kodları verilerek transkript edilerek katılımcıların onayına sunulmuştur. Görüşmeler yaklaşık 15 dakika sürmektedir. Görüşmeler 2020 yılı öncesinde yapılarak veriler toplanmıştır.

Birinci bölümde ebeveynlerin yaşı, cinsiyeti, aylık gelir durumu, eğitim düzeyi, çocuk/larınınyaşı,kaçyılındanveyılınhangiayındanitibarendergiaboneliğiolduğu ifadeleri yer almaktadır. İkinci bölümde ise değer kavramının ebeveyn için ne ifade ettiği, derginin beklentileri karşılayıp karşılamadığı, dergide değer kavramalarının yer alma durumuna ilişkin görüşleri, çocuklarına değer eğitimi ile ilgili ne kazandırdığı ve dergiye yönelik değer eğitimi ile ilgili önerilerinin neler olduğuna ilişkin beş soru yer almaktadır.

\section{Verilerin Analizi}

Çalışmada "Meraklı Minik" dergisinin (2007 Ocak - 2020 Aralık) sayılarından ve ebeveyn görüşmelerinden elde edilen verilerin analizinde nitel veri analizi yöntemlerinden içerik analizi kullanılmıştır. İçerik analizinde temel amaç, toplanan verilerin açılanması için kavram ve ilişkilere ulaşmaktır (Selçuk vd., 2014). İçerik analiziyle asıl yapılan toplanan verilerden birbirine benzer olanları belirli grup ve temalar şeklinde tasnif ederek okuyucunun anlaması için organize etmektir (Yıldırım ve Şimşek, 2013). 2007-2020 yılları arasında yayımlanan Meraklı Minik Dergisi'nin aylık sayılarında yer verilen değerlere ilişkin kodlar analiz edilmiştir.

Dergilerin incelenmesi aşamasında tasniflerin geçerlik ve güvenirliğini sağlamak amacıyla incelemelerde görüş birliği sağlamak esas alınmıştır. Bu doğrultuda tüm tasnifler iki araştırmacı tarafından ayrı ayrı değerlendirilmiştir. Yapılan değerlendirme sonucunun birbiri ile uyumlu olduğu görülmüş ve ardından 
ele alınan değerlerin tekrarlanma sıklığı ve yüzdeleri hesaplanarak yorumlar yapılmaya çalışılmıştır.

Ebevenlerin görüşleri transkiript edildikten sonra araştırmacılar tarafından kod, kategori ve temalar MAXQDA Analytics Pro 2018 (18.2.5) programı ile çözümlenerek modellemeler oluşturulmuştur. Araştırmadan bağımsız nitel çalışma konusunda bir alan uzmanına yazılı dokümanların \%20'si gönderilip uzmandan analiz etmesi istenmiştir. Araştırmacı ve alan uzmanının yapmış olduğu kod, kategori ve temaların birbiriyle uyumlu olduğu görülmüştür.

\section{Bulgular}

Yıllara göre "Meraklı Minik" dergisinde yer alan değerlere ilişkin tablolara ve ebeveyn görüşleri doğrultusunda oluşturulan şekillere verilmiştir.

Tablo 2: 2007 Y1lı Meraklı Minik Dergisinde Değerlerin Yüzde ve Frekans Tablosu

\begin{tabular}{|c|c|c|}
\hline \multicolumn{3}{|c|}{2007 Yilı } \\
\hline Değerler & f & $\%$ \\
\hline Estetik Duyguların Geliştirilmesi & 22 & 21,34 \\
\hline Bağımsız ve Özgür Düşünebilme & 10 & 9,70 \\
\hline Yardımlaşma, Dayanışma & 10 & 9,70 \\
\hline Aile Birliğine Önem Verme & 8 & 7,76 \\
\hline Hoşgörü/Duyarlılık & 6 & 5,82 \\
\hline Çalışkanlık & 7 & 6,79 \\
\hline Sorumluluk & 6 & 5,82 \\
\hline Dostluk & 5 & 4,85 \\
\hline Özgüven & 5 & 4,85 \\
\hline Fedakârlık & 5 & 4,85 \\
\hline Paylaşımcı Olma & 3 & 2,91 \\
\hline Temizlik & 3 & 2,91 \\
\hline Vatanseverlik & 3 & 2,91 \\
\hline Sevgi & 2 & 1,94 \\
\hline İyilik Yapma & 2 & 1,94 \\
\hline Selamlaşma & 2 & 1,94 \\
\hline Cesaret/Liderlik & 2 & 1,94 \\
\hline Empati & 1 & 0,97 \\
\hline Şefkat/Merhamet & 1 & 0,97 \\
\hline Toplam & 103 & 100 \\
\hline
\end{tabular}

Tablo 2 incelendiğinde 2007 yılında 103 yerde 19 farklı değere yer verildiği 
görülmüştür. Bu yıl içerisinde en çok estetik duyguların geliştirilmesi değerine $(\% 21,34)$ yer verilirken; empati, şefkat-merhamet değerlerine en az $(\% 0,97)$ yer verildiği tespit edilmiştir.

İyilik yapma değeri için Şubat sayısında "Kuşlar, kış mevsiminde yiyecek bulmakta zorlanırlar. Biz de kuşlar için süt kartonlarından kuş yemliği yaptık." ifadesine 20. sayfada rastlanmaktadır.

Yardımlaşma/dayanışma değeri için Mart sayısında "Karamel, saksılara koyacağ mizliyor." şeklinde derginin 16. sayfasında yer verilmiştir.

Tablo 3: 2008 Yılı Meraklı Minik Dergisinde Yer Alan Değerlerin Yüzde ve Frekans Tablosu

\begin{tabular}{|c|c|c|}
\hline \multicolumn{3}{|c|}{2008 Yılı } \\
\hline Değerler & f & $\%$ \\
\hline Estetik Duyguların Geliştirilmesi & 32 & 22,69 \\
\hline Yardımlaşma, Dayanışma & 19 & 13,47 \\
\hline Aile Birliğine Önem Verme & 13 & 9,21 \\
\hline Dayanışma & 9 & 6,38 \\
\hline Çalışkanlık & 8 & 5,67 \\
\hline Sorumluluk & 7 & 4,97 \\
\hline Fedakârlık & 6 & 4,25 \\
\hline İyilik Yapma & 6 & 4,25 \\
\hline Temizlik & 4 & 2,84 \\
\hline Selamlaşma & 4 & 2,84 \\
\hline Şefkat/Merhamet & 4 & 2,84 \\
\hline Kültürel Mirasa Sahip Çıkma & 4 & 2,84 \\
\hline Hoşgörü-duyarlılık & 3 & 2,13 \\
\hline Dostluk & 3 & 2,13 \\
\hline Empati & 3 & 2,13 \\
\hline Bağımsız ve Özgür Düşünebilme & 2 & 1,42 \\
\hline Özgüven & 2 & 1,42 \\
\hline Paylaşımcı Olma & 2 & 1,42 \\
\hline Vatanseverlik & 2 & 1,42 \\
\hline Sevgi & 2 & 1,42 \\
\hline Cesaret/Liderlik & 2 & 1,42 \\
\hline Misafirperverlik & 2 & 1,42 \\
\hline Sayg1 & 2 & 1,42 \\
\hline Toplam & 141 & 100 \\
\hline
\end{tabular}


Tablo 3 incelendiğinde 2008 yılında 141 yerde 23 farklı değere yer verildiği görülmektedir. 2008 yılı içerisinde en çok estetik duyguların geliştirilmesi değerine $(\% 22,69)$, en az bağımsız ve özgür düşünebilme, özgüven, paylaşımcı olma, vatanseverlik, sevgi, cesaret/liderlik, misafirperverlik, sayg1 $(\% 1,42)$ değerlerine yer verildiği görülmektedir.

Derginin Mart sayısının ikinci sayfasında yardımlaşma değerine "Karamel çöpleri çıkarmama yardım eder misin? Şu küçük poşeti de sen al lütfen. Geliyorum anne!" şeklinde yer verildiği görülmektedir.

Dayanışma için derginin Temmuz sayısında "Karamel'in annesi sebze çorbasını pişirirken çocuklar da reçel ve salatanın hazırlanmasında yardım ederler." ifadesiyle altıncı sayfada yer verilmiştir.

Estetik duyguların geliştirilmesi değeri için Kasım sayısının on dördüncü sayfasında şu şekilde yer verilmiştir; "Doruk, Ada, Sarp ve Elif bir müzik grubu kurmuşlar! Her biri ayrı bir müzik aleti çalıyor:..."

Tablo 4: 2009 Yılı Meraklı Minik Dergisinde Yer Alan Değerlerin Yüzde ve Frekans Tablosu

2009 Yll

\begin{tabular}{|c|c|c|}
\hline Değerler & f & $\%$ \\
\hline Estetik duyguların geliştirilmesi & 30 & 21,10 \\
\hline Yardımlaşma, Dayanışma & 15 & 10,49 \\
\hline Aile birliğine önem verme & 14 & 9,80 \\
\hline Bağımsız ve özgür düşünebilme & 12 & 8,40 \\
\hline Sorumluluk & 11 & 7,69 \\
\hline Çalışkanlık & 7 & 4,90 \\
\hline Sevgi & 6 & 4,19 \\
\hline İyilik yapma & 6 & 4,19 \\
\hline Kültürel mirasa sahip çıkma & 6 & 4,19 \\
\hline Fedakârlık & 5 & 3,49 \\
\hline Empati & 5 & 3,49 \\
\hline Dostluk & 4 & 2,79 \\
\hline Hoşgörü/Duyarlılık & 3 & 2,09 \\
\hline Nazik olma & 3 & 2,09 \\
\hline Şefkat/Merhamet & 2 & 1,39 \\
\hline Selamlaşma & 2 & 1,39 \\
\hline Temizlik & 2 & 1,39 \\
\hline Sayg1 & 2 & 1,39 \\
\hline Özgüven & 2 & 1,39 \\
\hline Vatanseverlik & 2 & 1,39 \\
\hline
\end{tabular}




\begin{tabular}{lll}
\hline İyimserlik & 2 & 1,39 \\
\hline Misafirperverlik & 1 & 0,70 \\
\hline Cesaret/Liderlik & 1 & 0,70 \\
\hline Toplam & $\mathbf{1 4 3}$ & $\mathbf{1 0 0}$ \\
\hline
\end{tabular}

Tablo 4'te 2009 yılında 143 yerde 23 farklı değere yer verildiği görülmektedir. Bu yıl içerisinde en çok \%21,10'lık oran ile estetik duyguların geliştirilmesi ve \%10,49’luk oran ile yardımlaşma, dayanışma değerlerine yer verilirken; $\% 0,70$ 'lik oran ile en az misafirperverlik ve cesaret-liderlik değerlerine yer verildiği tespit edilmiştir.

Bağımsız ve özgür düşünebilme değeri için derginin Mayıs sayısında "Karşıya geçmek için burada gördüğün merdiven, kayık, salyangoz kabuğu gibi malzemelerden hangilerini kullanırdın?" ifadesiyle altıncı sayfada yer verilmiştir.

Derginin yine Mayıs sayısının yirmi sekizinci sayfasında iyilik yapma ve dayanışma değerlerine "Bir karınca yiyecek bulunca yere koku bırakarak arkadaşlarına haber verir. Diğer karıncalar da bu kokuyu izleyerek yiyeceğe ulaşır." şeklinde yer verildiği görülmektedir.

Tablo 5: 2010 Y1lı Meraklı Minik Dergisinde Yer Alan Değerlerin Yüzde ve Frekans Tablosu 2010 Yilı

\begin{tabular}{lll}
\hline Değerler & $\mathbf{f}$ & $\mathbf{\%}$ \\
\hline Yardımlaşma, Dayanı̧̧ma & 30 & 18,18 \\
\hline Estetik duyguların geliştirilmesi & 24 & 14,54 \\
\hline Bağımsız ve özgür düşünebilme & 18 & 10,90 \\
\hline Aile birliğine önem verme & 15 & 9,09 \\
\hline Dostluk & 10 & 6,60 \\
\hline Sorumluluk & 8 & 4,84 \\
\hline Sevgi & 8 & 4,84 \\
\hline Temizlik & 7 & 4,24 \\
\hline Fedakârlık & 6 & 3,63 \\
\hline Şefkat/Merhamet & 6 & 3,63 \\
\hline İyilik yapma & 4 & 2,42 \\
\hline Özgüven & 4 & 2,42 \\
\hline Cesaret/Liderlik & 4 & 2,42 \\
\hline Selamlaşma & 3 & 1,81 \\
\hline Çalışkanlık & 3 & 1,81 \\
\hline Saygı & 3 & 1,81 \\
\hline İyimserlik & 3 & 1,81 \\
\hline Misafirperverlik & 21 \\
\hline
\end{tabular}




\begin{tabular}{lll}
\hline Kültürel mirasa sahip çıkma & 2 & 1,21 \\
\hline Alçakgönüllülük & 2 & 1,21 \\
\hline Empati & 1 & 0,60 \\
\hline Hoşgörü/Duyarlılık & 1 & 0,60 \\
\hline Vatanseverlik & 1 & 0,60 \\
\hline Toplam & $\mathbf{1 6 5}$ & $\mathbf{1 0 0}$ \\
\hline
\end{tabular}

Tablo 5'e bakıldığında 2010 yılında 165 yerde 23 farklı değere yer verildiği görülmektedir. Bu yıl içerisinde en çok yardımlaşma, dayanışma ve estetik duyguların geliştirilmesi değerlerine sırasıyla $\% 14,54$ ve $\% 10,90$ oranlarında yer verilirken; en az empati, hoşgörü-duyarlılık ve vatanseverlik değerleri \%0,60 oranında yer almaktadir.

Derginin Nisan sayısının on beşinci sayfasında sorumluluk ve aile birliğine önem verme değerlerine "Şu yavru kuğulara bak! Yavru kuğulara anne ve baba kuğu birlikte bakar. Biri yiyecek bulmaya gittiğinde öteki yavrularla birlikte kalır. Yavrularına yüzmeyi ve yiyecek bulmayı öğretirler” şeklinde yer verildiği görülmektedir.

Kültürel mirasa sahip çıkma değeri için derginin Haziran sayısında "Ilgaz ve Şebnem, oyuncak müzesine geldiler. Girişteki görevliden biletlerini alıp içeri girdiler." ifadesiyle onuncu sayfada yer verilmiştir.

DostlukdeğeriiçinKasımayında "Yabaniatlar,büyükyeşilçayırlardahepbirlikte dolaşmayı çok sever. Birbirlerinden hiç ayrılmazlar.” şeklinde on yedinci sayfada yer verilmiştir.

Tablo 6: 2011 Yılı Meraklı Minik Dergisinde Yer Alan Değerlerin Yüzde ve Frekans Tablosu

\begin{tabular}{lll}
\hline & $\mathbf{2 0 1 1}$ Yılı & \\
\hline Değerler & $\mathbf{f}$ & $\mathbf{\%}$ \\
\hline Estetik duyguların geliştirilmesi & 37 & 18,04 \\
\hline Yardımlaşma, Dayanışma & 35 & 17,07 \\
\hline Sorumluluk & 25 & 12,19 \\
\hline Aile birliğine önem verme & 24 & 11,70 \\
\hline Bağımsız ve özgür düşünebilme & 16 & 7,80 \\
\hline Fedakârlık & 15 & 7,31 \\
\hline Hoşgörü/Duyarlılık & 7 & 3,41 \\
\hline İyilik yapma & 7 & 3,41 \\
\hline Dostluk & 5 & 2,43 \\
\hline Çalışkanlık & 5 & 2,43 \\
\hline Sevgi & 4 & 1,96 \\
\hline
\end{tabular}




\begin{tabular}{lll}
\hline Şefkat/Merhamet & 4 & 1,96 \\
\hline Saygı & 4 & 1,96 \\
\hline Cesaret/Liderlik & 4 & 1,96 \\
\hline Kültürel mirasa sahip çıkma & 3 & 1,47 \\
\hline Empati & 2 & 0,98 \\
\hline Paylaşımcı olma & 2 & 0,98 \\
\hline Vatanseverlik & 2 & 0,98 \\
\hline Temizlik & 1 & 0,49 \\
\hline Özgüven & 1 & 0,49 \\
\hline İyimserlik & 1 & 0,49 \\
\hline Alçakgönüllülük & 1 & 0,49 \\
\hline Toplam & $\mathbf{2 0 5}$ & $\mathbf{1 0 0}$ \\
\hline
\end{tabular}

Tablo 6'i incelediğimizde 2011 yılında 205 yerde 22 farklı değere yer verildiği görülmektedir. 2011 yılı içerisinde en çok estetik duyguların geliştirilmesi değerine $(\% 18,04)$ ve yardımlaşma, dayanışma değerlerine $(\% 17,07)$ oranlarında yer verilirken; en az temizlik, özgüven, iyimserlik, alçakgönüllülük değerlerine $\% 0,49$ oranında yer verildiği görülmektedir.

Estetik duygulara yer verme değeri için derginin Mart sayısında "Şapkayı takan kişi dans etmeye başlasın. Diğer oyuncular da onun yaptığı dans hareketlerinin aynısını yapmaya çalışsın.” ifadesiyle otuz üçüncü sayfada yer verilmiştir. Derginin Ağustos sayısının altıncı sayfasında kültürel mirasa sahip çıkma değerine “İki arkadaş, Güllük Dağı Milli Parkı’nın girişindeler.

Dağın yukarısında kalıntılar var. Bu kalıntılar, eski zamanlardan kalma Termessos kentine ait. İki arkadaş oraya gitmek istiyor.” şeklinde yer verildiği görülmektedir.

Tablo 7: 2012 Yılı Meraklı Minik Dergisinde Yer Alan Değerlerin Yüzde ve Frekans Tablosu

\begin{tabular}{lll}
\hline & $\mathbf{2 0 1 2}$ Yılı & \\
\hline Değerler & $\mathbf{f}$ & $\mathbf{\%}$ \\
\hline Estetik Duyguların Geliştirilmesi & 20 & 17,24 \\
\hline Hoşgörü/Duyarlılık & 16 & 13,79 \\
\hline Çalışkanlık & 10 & 8,62 \\
\hline Sorumluluk & 9 & 7,75 \\
\hline Yardımlaşma, Dayanışma & 9 & 7,75 \\
\hline Cesaret, Liderlik & 6 & 5,17 \\
\hline Aile Birliğine Önem Verme & 6 & 5,17 \\
\hline Sevgi & 5 & 4,31 \\
\hline
\end{tabular}




\begin{tabular}{lll}
\hline Şefkat/Merhamet & 5 & 4,31 \\
\hline Iyilik Yapma & 4 & 3,44 \\
\hline Dostluk & 3 & 2,58 \\
\hline Empati & 3 & 2,58 \\
\hline Nazik Olma & 3 & 2,58 \\
\hline Selamlaşma & 3 & 2,58 \\
\hline Kültürel Mirasa Sahip Çıkma & 3 & 2,58 \\
\hline Özgüven & 2 & 1,72 \\
\hline Paylaşımcı Olma & 2 & 1,72 \\
\hline Temizlik & 2 & 1,72 \\
\hline Bağımsız ve Özgür Düşünebilme & 2 & 1,72 \\
\hline İyimserlik & 1 & 0,86 \\
\hline Misafirperverlik & 1 & 0,86 \\
\hline Saygı & 1 & 0,86 \\
\hline Toplam & 116 & 100 \\
\hline
\end{tabular}

Tablo 7 incelendiğinde 2012 Meraklı Minik dergisi sayılarında 116 yerde 22 farklı değere yer verildiği görülmektedir. 22 farklı değere yer verilirken adil olma, fedakârlık ve vatanseverlik değerlerine rastlanmamıştır. \%17,24 lük oranla en fazla estetik duyguların geliştirilmesi değeri ön plana çıkmaktadır. $\% 0,86$ oranıyla da en az iyimserlik, misafirperverlik ve saygı değerlerine yer verilmiştir.

2012 yılı ocak ayının yirmi beşinci sayfasında nazik olma değerine “... Bunun üzerine annesi "Teyzene teşekkür etmek ister misin? dedi. ..." cümlesi örnek olarak gösterilebilir.

"Yoldaki diğer araçlar, itfaiye aracının geçebilmesi için ona yol veriyor. Bu bir trafik kuralı! İtfaiye aracının gideceği yere çabuk ulaşabilmesi için diğer araçlar ona yol verir." cümleleri de haziran ayı yirmi ikinci sayfada yer alırken dayanışma için örnek verilebilir.

Eylül ayı sayısında yedinci sayfada yer alan "Bu pelikanın tüylerine petrol bulaşmış. Çünkü yaşadığı yerin yakınlarında bir tanker kazası olmuş ve denize petrol dökülmüş. Doğa korumacılar pelikanın tüylerindeki petrolü temizliyorlar. Daha sonra onu yaşadığı yere geri bırakacaklar." metninde duyarlılık ve iyilik yapma değerine yer verildiği görülmektedir. 
Tablo 8: 2013 Yılı Meraklı Minik Dergisinde Yer Alan Değerlerin Yüzde ve Frekans Tablosu

\begin{tabular}{|c|c|c|}
\hline \multicolumn{3}{|c|}{2013 Yilı } \\
\hline Değerler & f & $\%$ \\
\hline Çalışkanlık & 20 & 20 \\
\hline Estetik Duyguların Geliştirilmesi & 20 & 20 \\
\hline Sorumluluk & 11 & 11 \\
\hline Bağımsız ve Özgür Düşünebilme & 10 & 10 \\
\hline Yardımlaşma, Dayanışma & 10 & 10 \\
\hline Selamlaşma & 7 & 7 \\
\hline Kültürel Mirasa Sahip Çıkma & 6 & 6 \\
\hline Sevgi & 3 & 3 \\
\hline Aile Birliğine Önem Verme & 2 & 2 \\
\hline Hoşgörü/Duyarlılık & 2 & 2 \\
\hline Temizlik & 2 & 2 \\
\hline Şefkat/Merhamet & 2 & 2 \\
\hline Empati & 1 & 1 \\
\hline Fedakârlık & 1 & 1 \\
\hline Özgüven & 1 & 1 \\
\hline Paylaşımcı Olma & 1 & 1 \\
\hline Sayg1 & 1 & 1 \\
\hline Toplam & 100 & 100 \\
\hline
\end{tabular}

2013 y1lı değerler tablosu olan tablo 8 incelendiğinde 100 yerde 17 farkl1 değere yer verildiği görülmektedir. Geçmiş y1lların çoğunda olduğu gibi bu y1l da en fazla estetik duyguların geliştirilmesi değerine yer verildiği görülmektedir. Bunun yanında \%20'lik değerle çalışkanlık değeri de yine ilk sıralarda yer almaktadır. \%1'lik oran ile en az empati, fedakarlık, özgüven, paylaşımcı olma ve sayg1 değerlerine yer verildiği görülmektedir.

“... Fırıncılar da sabah olmadan ekmekleri pişirmek için gece çalışıyor... Bazı taksi ve otobüs şoförleri de geceleri işbaşında ...” ifadesi ile şubat ayı sayısının onuncu sayfasında çalışkanlık değerine yer verilirken “... Daha sonra fosili incelemek için araştırma laboratuvarına götürüyorlar. Taşıma sırasında zarar görmemesi için fosilin parçalarını alçıyla kaplıyorlar ..." ifadesi mart sayısı on ikinci sayfada yer alıp kültürel mirasa sahip çıkma değerine örnek verilebilir.

Eylül ayı sayısında yirmi sekizinci ve yirmi dokuzuncu sayfalarda yer alan Kahvaltı Treni etkinliği ile estetik düşüncenin geliştirilmesi değeri ön plana çıkarken aynı zamanda özgür ve bağımsız düşünmenin de amaçlandığı düşünülmektedir. 
Tablo 9: 2014 Yılı Meraklı Minik Dergisinde Yer Alan Değerlerin Yüzde ve Frekans Tablosu

\begin{tabular}{|c|c|c|}
\hline \multicolumn{3}{|c|}{2014 Yılı } \\
\hline Değerler & f & $\%$ \\
\hline Bağımsız ve Özgür Düşünebilme & 22 & 18,96 \\
\hline Temizlik & 18 & 15,51 \\
\hline Yardımlaşma, Dayanışma & 17 & 14,65 \\
\hline Estetik Duyguların Geliştirilmesi & 14 & 12,06 \\
\hline Hoşgörü/Duyarlılık & 11 & 9,48 \\
\hline Sorumluluk & 6 & 5,17 \\
\hline Sevgi & 5 & 4,31 \\
\hline Selamlaşma & 4 & 3,44 \\
\hline Şefkat/Merhamet & 4 & 3,44 \\
\hline Empati & 3 & 2,58 \\
\hline Fedakârlık & 2 & 1,72 \\
\hline İyimserlik & 2 & 1,72 \\
\hline Özgüven & 2 & 1,72 \\
\hline Dostluk & 1 & 0,86 \\
\hline Aile Birliğine Önem Verme & 1 & 0,86 \\
\hline Nazik Olma & 1 & 0,86 \\
\hline Paylaşımcı Olma & 1 & 0,86 \\
\hline Cesaret/Liderlik & 1 & 0,86 \\
\hline Kültürel Mirasa Sahip Çıkma & 1 & 0,86 \\
\hline Toplam & 116 & 100 \\
\hline
\end{tabular}

Tablo 9 incelendiğinde 116 yerde 19 farklı değer yer almaktadır. Bağımsız ve özgür düşünebilme, temizlik ve yardımlaşma-dayanışma gibi değerlere sıkça yer verilirken vatanseverlik, adil olma, cesaret, misafirperverlik gibi değerlere yer verilmediği görülmektedir. 2014 yılında \%18,96 oranı ile en fazla bağımsız ve özgür düşünebilme değerine yer verilirken en az \%0,86’l1k oran ile dostluk, aile birliğine önem verme, nazik olma, paylaşımcı olma, cesaret-liderlik, kültürel mirasa sahip çıkma değerlerine yer verilmiştir.

2014 yılı Mart ayı sayısının onuncu sayfasında bağımsız ve özgür düşünebilme değerine "Evdeki malzemelerle farklı kuklalar yapabilirsin. Örneğin bir çorap kukla. Çorap kuklaya kumaş, keçe ya da kartondan yaptığın göz, ağız, burun, kulak gibi parçaları yapıştır.” şeklinde yer verildiği görülmektedir. Yine ağustos ayı sayısında "Bazı hayvan topluluklarında, anne ve baba hayvanlar yiyecek aramaya gittiğinde bütün yavrular bir araya toplanır. Birkaç yetişkin yiyecek aramaya gitmez ve yavruların yanında kalır. Anne ve babaları dönene 
kadar yavru hayvanlarla bu yetişkinler ilgilenir." metni yardımlaşma, dayanışma değerlerine örnek olarak verilebilir (Sayfa 17).

“Ancak çoğu hayvan göç ederken kalabalık sürüler oluşturur. Sürüdekilerden biri ya da birkaçı en önde giderek diğerlerine yol gösterir" cümleleri de ekim ayı sayısında geçen liderlik değerine örnek gösterilebilir (Sayfa 26).

\begin{tabular}{|c|c|c|}
\hline \multicolumn{3}{|c|}{2015 Yılı } \\
\hline Değerler & f & $\%$ \\
\hline Hoşgörü/Duyarlılık & 13 & 15,47 \\
\hline Yardımlaşma, Dayanışma & 11 & 13,09 \\
\hline Bağımsız ve Özgür Düşünebilme & 10 & 11,90 \\
\hline Sorumluluk & 9 & 10,71 \\
\hline Estetik Duyguların Geliştirilmesi & 8 & 9,52 \\
\hline Selamlaşma & 6 & 7,14 \\
\hline Şefkat/Merhamet & 5 & 5,95 \\
\hline Sevgi & 4 & 4,76 \\
\hline Nazik Olma & 3 & 3,57 \\
\hline Çalışkanlık & 3 & 3,57 \\
\hline Kültürel Mirasa Sahip Çıkma & 2 & 2,38 \\
\hline İyimserlik & 2 & 2,38 \\
\hline Temizlik & 2 & 2,38 \\
\hline Aile Birliğine Önem Verme & 1 & 1,19 \\
\hline Adil Olma & 1 & 1,19 \\
\hline Dostluk & 1 & 1,19 \\
\hline Sayg1 & 1 & 1,19 \\
\hline Paylaşımcı Olma & 1 & 1,19 \\
\hline İyilik Yapma & 1 & 1,19 \\
\hline Toplam & 84 & 100 \\
\hline
\end{tabular}

2015 y1lında toplamda 84 yerde 19 farklı değere yer verilmiştir. Tablo 10 incelenmiş ve en fazla \%15,47 oranla hoşgörü-duyarlılık ve \%13,09 oranla yardımlaşma-dayanışma değerine yer verildiği, en az \%1,19'luk değerle adil olma, dostluk, aile birliğine önem verme, saygı, paylaşımcı olma, iyilik yapma değerlerine yer verildiği görülmüştür.

2015 yılı Ocak ayı sayısının otuz dördüncü sayfasında selamlaşma ve nazik olma değeri için "Merhaba, benim adım Bodi. Ece beni kumbarasında biriktirdiği paralarla kardeşine doğum günü hediyesi olarak aldı" cümleleri örnek gösterilebilir. 
Duyarlılık değerine "Bu fotoğraftaki yavru turnalar bir koruma merkezinde yumurtadan çıkmış. Yanlarındakiyse yetişkin bir turnaya benzemek için kostüm giymiş bir doğa korumacı" metni duyarlılık değeri için örnek gösterilebilir (sayfa 14).

Ekim ayı sayısının ikinci sayfasında yer alan şu metin aile birliğine önem verme değeri için örnek verilebilir: "Çok seviyorum o kitabı. Çünkü Güneş’i anlatıyor. Benim adım da Güneş ben de bu kitabı çok seviyorum kızım. Ama seni daha çok seviyorum."

Tablo 11: 2016 Yılı Meraklı Minik Dergisinde Yer Alan Değerlerin Yüzde ve Frekans Tablosu

2016 Yılı

\begin{tabular}{lll}
\hline Değerler & $\mathbf{f}$ & $\mathbf{\%}$ \\
\hline Estetik Duyguların Geliştirilmesi & 15 & 15,95 \\
\hline Sorumluluk & 15 & 15,95 \\
\hline Bağımsız ve Özgür Düşünebilme & 12 & 12,76 \\
\hline Çalışkanlık & 11 & 11,70 \\
\hline Yardımlaşma, Dayanışma & 7 & 7,44 \\
\hline Kültürel Mirasa Sahip Çıkma & 6 & 6,38 \\
\hline Hoşgörü/Duyarlılık & 6 & 6,38 \\
\hline Sevgi & 6 & 6,38 \\
\hline Selamlaşma & 5 & 5,31 \\
\hline Temizlik & 4 & 4,25 \\
\hline Aile Birliğine Önem Verme & 1 & 1,06 \\
\hline Vatanseverlik & 1 & 1,06 \\
\hline Misafirperverlik & 1 & 1,06 \\
\hline Paylaşımcı Olma & 1 & 1,06 \\
\hline Cesaret/Liderlik & 1 & 1,06 \\
\hline İyimserlik & 1 & 1,06 \\
\hline Şefkat/Merhamet & 1 & 1,06 \\
\hline Toplam & 94 & 100 \\
\hline Täblo & 1 & 1 \\
\hline
\end{tabular}

Tablo 11'de 94 yerde 18 farklı değere yer verilmiştir. 2016 y1lında $\% 15,95$ oran ile estetik duyguların geliştirilmesi ve sorumluluk değerlerine en fazla yer verilmiştir. \%1,06'l1k oran ile en az aile birliğine önem verme, vatanseverlik, misafirperverlik, paylaşımcı olma, cesaret-liderlik, iyimserlik, ve şefkat-merhamet değerlerine yer verilmiştir. Adil olma, fedakârlık, dostluk, nazik olma, sayg1, empati, özgüven, iyilik yapma gibi değerlere yer verilmemiştir.

Mart ayı sayısı sayfa on birde yardımlaşma ve merhamet değerine "Deniz' in kedisi bir ağaca tırmanmış. Ama sonra ağaçtan inememiş ve miyavlamaya başlamış... Bir komşuları bir merdiven getirmiş. Merdiveni ağaca dayamış. Sonra 
merdivene çıkarak kediyi ağaçtan indirmiş." örnek gösterilebilir.

Çalışkanlık ve sorumluluk değerleri için mayıs ayı sayısının altıncı sayfasında yer alan "Bu fotoğraf da buzların arasındaki başka bir gemide çekilmiş. Burada gördüğün Türk bilim insanları geçtiğimiz günlerde bu gemiyle Antarktika kıtasına gittiler, yolculukları boyunca gözlemler yaptılar" cümleleri örnek verilebilir.

Ekim ayı sayısının on yedinci sayfasında "Karşınızda sebze orkestrası! Burada gördüğün müzisyenler, sebzelerden yaptıkları müzik aletleriyle bir konser veriyorlar" cümleleri bağımsız ve özgür düşünebilme değerine örnek verilebilir.

Tablo 12: 2017 Yılı Meraklı Minik Dergisinde Yer Alan Değerlerin Yüzde ve Frekans Tablosu

\begin{tabular}{|c|c|c|}
\hline \multicolumn{3}{|c|}{2017 Yılı } \\
\hline Değerler & f & $\%$ \\
\hline Yardımlaşma, Dayanışma & 43 & 37,7 \\
\hline Estetik duyguların geliştirilmesi & 20 & 17,5 \\
\hline Sevgi & 11 & 9,6 \\
\hline Sorumluluk & 7 & 6,1 \\
\hline Sayg1 & 6 & 5,3 \\
\hline Temizlik & 5 & 4,4 \\
\hline Fedakârlık & 5 & 4,4 \\
\hline Bağımsız ve özgür düşünebilme & 4 & 3,5 \\
\hline Dostluk & 4 & 3,5 \\
\hline Özgüven & 3 & 2,6 \\
\hline Hoşgörü/Duyarlılık & 3 & 2,6 \\
\hline Kültürel mirasa sahip çıkma & 2 & 1,8 \\
\hline Paylaşımcı olmak & 1 & 0,9 \\
\hline Toplam & 114 & 100 \\
\hline
\end{tabular}

Tablo 12 incelendiğinde 2017 y1lı Meraklı Minik dergisinde 114 değere rastlanmıştır. Bu değerler 13 farklı temadadır. En fazla \%37,7'lik oran ile yardımlaşma, dayanışma değerine yer verilirken \%0,9'luk oran ile en az paylaşımcı olmak değerine yer verildiği görülmektedir. Çalışkanlık, cesaret, adil olma, misafirperverlik gibi değerlere de rastlanmamıştır.

Özgüven değeri için ocak ayı sayısı sayfa dörtte yer alan "İmparator penguenler çok iyi yüzebilir, hatta çok iyi dalabilir.” Cümlesi örnek gösterilirken dostluk değerine ise mart ayı sekizinci sayfasında yer alan "Bu küçük kurbağanın bir sürü arkadaşı var. Arkadaşlarından bazıları suda, bazıları karada yaşıyor. Kara- 
da yaşayanların bazılarıysa ağaçlardan hiç inmiyor." cümleleri örnek verilebilir.

Fedakârlık, sevgi ve sorumluluk değerleri için eylül ayı sayısı sayfa üç, dört ve beşte yer alan “...Ş̧imdi de yumurtaların üzerini örtüyor. Çünkü yumurtaların sıcak ve güvende olmaları gerekiyor. Böylece her bir yumurtadan birer yavru timsah çıkabilecek... Anne timsah yavruları tek tek ağzına alıyor. Bunu onları nehre taşımak için yapıyor. Neyse ki aynı anda 15 kadar yavruyu ağzında tutabiliyor!" metni örnek verilebilir.

Tablo 13: 2018 Yılı Meraklı Minik Dergisinde Yer Alan Değerlerin Yüzde ve Frekans Tablosu

2018 Yılı

\begin{tabular}{lll}
\hline Değerler & $\mathbf{f}$ & $\mathbf{\%}$ \\
\hline Yardımlaşma, Dayanışma & 57 & 41,9 \\
\hline Estetik duyguların geliştirilmesi & 20 & 14,7 \\
\hline Kültürel mirasa sahip çıkma & 20 & 14,7 \\
\hline Paylaşımcı olmak & 11 & 8,1 \\
\hline Bağımsız ve özgür düşünebilme & 8 & 5,9 \\
\hline Özgüven & 6 & 4,4 \\
\hline Sevgi & 6 & 4,4 \\
\hline Temizlik & 2 & 1,5 \\
\hline Fedakârlık & 2 & 1,5 \\
\hline Selamlaşma & 2 & 1,5 \\
\hline Saygı & 1 & 0,7 \\
\hline Dostluk & 1 & 0,7 \\
\hline Toplam & 1 & $\mathbf{1 0 0}$ \\
\hline
\end{tabular}

Tablo 13 incelendiğinde 136 yerde 12 farklı değere yer verildiği görülmektedir. \%41,9'luk oranla 57 farklı yerde yardımlaşma, dayanışma değerine rastlanmıştır. En fazla rastlanan değer yardımlaşma, dayanışma değeri olurken en az $(\% 0,7)$ saygı ve dostluk değerlerine rastlanmıştır. Ayrıca 2018 yılı içerisinde vatanseverlik, çalışkanlık, sabır, sorumluluk değerlerine rastlanmamıştır.

Nisan ayı sayısı on ikinci sayfada yer alan şu cümleler kültürel mirasa sahip çıkma değeri için örnek olarak gösterilebilir: "Önce Emirgân Korusu'na gidecekler. Sonra Beylerbeyi Sarayı'nı gezecekler. Ardından Dolmabahçe Sarayı'na gidecekler. Buradan çıkınca Mısır Çarşısı'nda alışveriş yapacaklar. En son gezecekleri yerse Miniatürk."

Selamlaşma değeri için eylül ayı sayısı yedinci sayfadaki "Bak palyaço balığı selam veriyor." cümlesi örnek gösterilirken kasım ayı sayısı beşinci sayfada 
paylaşımcı olma değeri için şu cümlelere yer verilmiştir: "Çıkan zeytinyağını ailecek paylaşacaklar.”

Tablo 14: 2019 Yılı Meraklı Minik Dergisinde Yer Alan Değerlerin Yüzde ve Frekans Tablosu 2019 Yil1

\begin{tabular}{lll}
\hline Değerler & $\mathbf{f}$ & $\mathbf{\%}$ \\
\hline Yardımlaşma, Dayanışma & 58 & 36,9 \\
\hline Temizlik & 22 & 14,0 \\
\hline Estetik duyguların geliştirilmesi & 20 & 12,7 \\
\hline Sevgi & 18 & 11,5 \\
\hline Sabır & 12 & 7,6 \\
\hline Dostluk & 8 & 5,1 \\
\hline Bağımsız ve özgür düşünebilme & 7 & 4,5 \\
\hline Sorumluluk & 7 & 4,5 \\
\hline Özgüven & 2 & 1,3 \\
\hline Selamlaşma & 2 & 1,3 \\
\hline Kültürel mirasa sahip çıkma & 1 & 0,6 \\
\hline Toplam & $\mathbf{1 5 7}$ & $\mathbf{1 0 0}$ \\
\hline
\end{tabular}

2019 yılı için oluşturulan tablo 14 incelendiğinde 157 yerde 11 farklı değere yer verildiği görülmektedir. \%36,9'luk oranla en fazla yardımlaşma, dayanışma değerine, \%0,6’lık oranla en az kültürel mirasa sahip çıkma değerine yer verilmiştir. Fedakârlık, vatanseverlik, cesaret, liderlik gibi değerlere yer verilmediği gözlenmiştir.

Sabır değeri için mayıs ayı sayısı üçüncü sayfadaki "Üç belki dört hafta sonra yaz sonuna varınca küçük yumurtalar çatladı. İçlerinden larvalar çıktı.” Cümleleri örnek gösterilebilir.

Estetik duyguların geliştirilmesi değeri için temmuz ayı sayısı yirmi dokuzuncu sayfadaki "Zeytin ezmesinin kalanını ve kaşar peynirinden keseceğiniz ince parçaları kullanarak fokların gözlerini, burunlarını ve bıyıklarını yapın. Kayalıkları yapmak için ekmekten iki parça kesin. Ekmek parçalarının üzerine krem peynir sürün. Bu parçaları fokların altına yerleştirin. Salatalığı soyun, uzun ve ince dilimler hâlinde doğrayın. Salatalık parçalarını kayaların arasına dizerek denizi ve dalgaları yapın..." cümlelerine yer verilmiştir.

Sevgi ve dostluk değeri için eylül ayı sayısı üçüncü sayfada yer alan "Ama Tırtır, içlerinde en sevdiğim. Çünkü o benim arkadaşım. Üstelik de komşum.” cümleleri örnek verilebilir. 


\begin{tabular}{|c|c|c|}
\hline \multicolumn{3}{|c|}{2020 Yılı } \\
\hline Değerler & f & $\%$ \\
\hline Yardımlaşma, Dayanışma & 96 & 61,1 \\
\hline Estetik duyguların geliştirilmesi & 43 & 27,4 \\
\hline Temizlik & 21 & 13,4 \\
\hline Sevgi & 20 & 12,7 \\
\hline Dostluk & 11 & 7,0 \\
\hline Selamlaşma & 10 & 6,4 \\
\hline Bağımsız ve özgür düşünebilme & 8 & 5,1 \\
\hline Sabir & 4 & 2,5 \\
\hline Kültürel mirasa sahip çıkma & 1 & 0,6 \\
\hline Toplam & 214 & 100 \\
\hline
\end{tabular}

Tablo 15 incelendiğinde 214 yerde 9 farklı değere yer verildiği görülmektedir. $\% 61,1^{\prime}$ lik oranla yardımlaşma, dayanışma değerine, \%27,4'lük oranla estetik duyguların geliştirilmesi, \%13,4'lük oranla temizlik, \%12,7'lik oranla sevgi, $\% 7$ 'lik oranla dostluk, $\% 6,4$ 'lük oranla selamlaşma, $\% 5,1^{\prime}$ 'lik oranla bağımsız ve özgür düşünebilme, $\% 2,5^{\prime}$ lik oranla sabır ve $\% 0,6$ 'lık oranla kültürel mirasa sahip çıkma değerlerine yer verildiği görülmektedir.

Temizlik değeri için nisan ayı sayısı ikinci sayfada yer alan "Uyanır uyanmaz önce tüylerini temizleyip düzeltiyorlar." cümleleri örnek gösterilebilir.

Bağımsız ve özgür düşünebilme değeri için mayıs ayı sayısı on yedinci sayfada yer alan "Sen de yüzen bir evde yaşamak ister miydin? Haydi, bir kâğıda hayalindeki yüzen evi çiz." metni örnek gösterilebilir.

Temizlik değeri için ekim ayı sayısı yirmi dokuzuncu sayfasında yer alan "Önce ellerinizi sabun ve suyla yıkayarak temizleyin. Sonra meyveleri bol su ile iyice yıkayın.” cümleleri örnek gösterilebilir. 


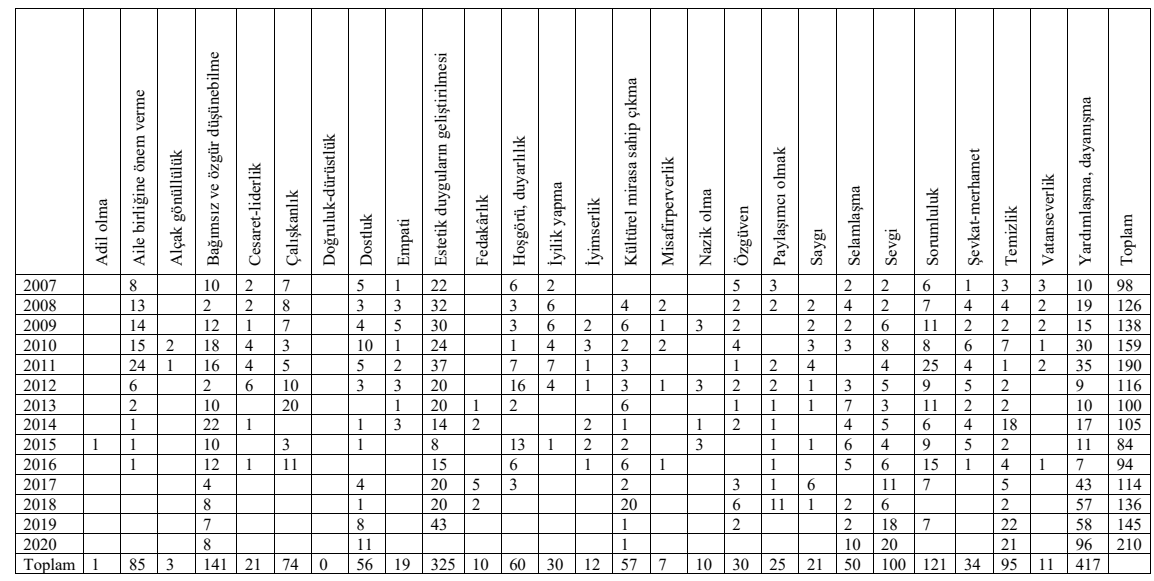

Şekil 1: 2007-2020 Y1lları Arasında Yayımlanan Meraklı Minik Dergisi’nde Yer Alan

Değerler

Şekil 1 incelendiğinde Meraklı Minik Dergisi 2007 ve 2020 yılları arasında çıkan sayılarda 26 farklı değer ele alınmıştır. Bu sayılarda en fazla yardımlaşma dayanışma (N:417) ve estetik duyguların geliştirilmesi (N:325) değerlerine rastlanırken en az adil olma (N:1), alçak gönüllülük (N:7), misafirperverlik (N:7), nazik olma (10), fedakârlık (N:10), vatanseverlik (N:11) değerine yer verildiği görülmüştür. Adil olma değerine sadece 2015 yılında, alçakgönüllülük değerine 2010 ve 2011 yıllarında yer verildiği görülürken derginin yayımlanmaya başlandığı 2007 yılından itibaren 2020 yılına kadar çıkan sayılarında doğruluk, dürüstlük değerlerine yer verilmediği görülmektedir. Buna karşın bağımsız ve özgür düşünebilme, estetik duyguların geliştirilmesi, sevgi ve temizlik değerlerine her yıl yer verildiği belirlenmiş̧tir. Meraklı Minik Dergisi'nin incelenen sayılarında, değerlere; en fazla 2020 yılında (N:210), en az ise 2015 (N:84) yılında yer verildiği saptanmıştır.

\section{Ebeveyn Görüşleri}

Meraklı Minik Dergisi kullanıcıları olan ebeveynlerle yapılan görüşmelerde; dergiye abone olma süreçleri, derginin çocuğa kazandırdığı değerler gibi soruların cevaplarına görüşme yoluyla ulaşılmış ve yapılan görüşme sonuçları tematik analizlerle modellenmiştir. 


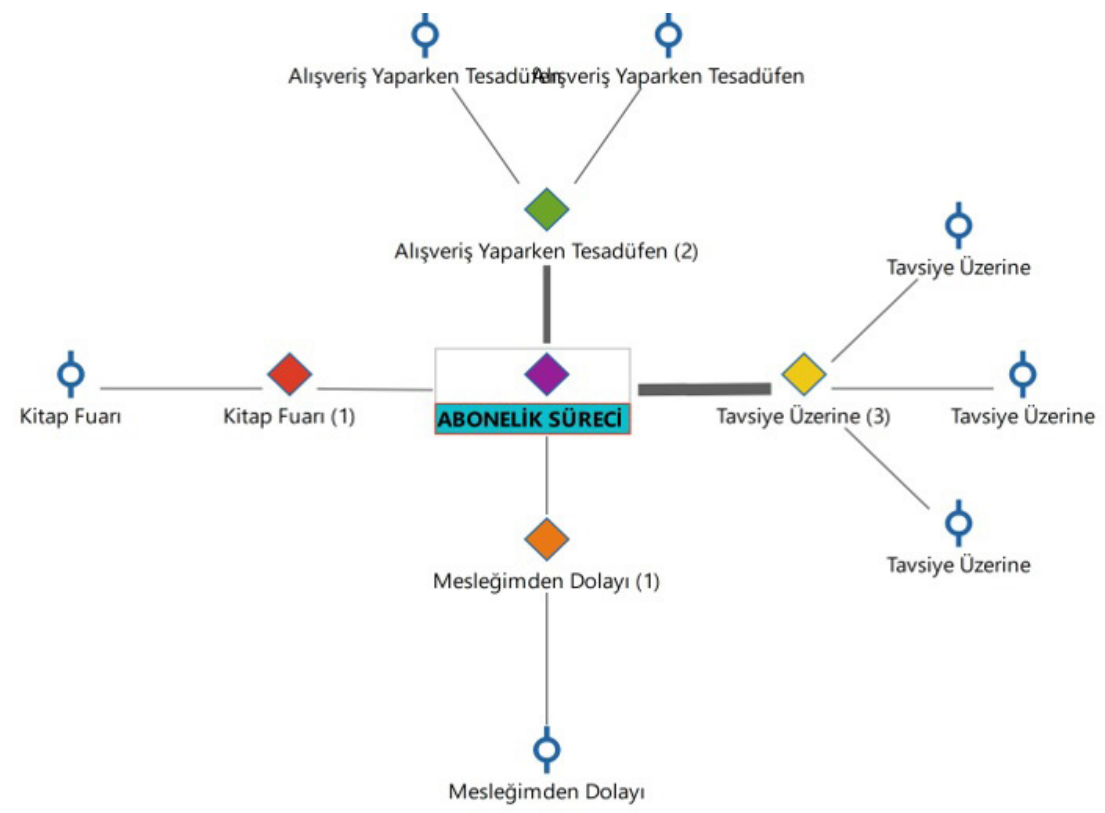

Şekil 2: Meraklı Minik Dergisi Tercih Etme Nedeni

Şekil 2 incelendiğinde katılımcıların dergi ile tanışmaları; tavsiye üzerine, alışveriş yaparken tesadüfen fark etme, kitap fuarında rastlama ve meslekten dolayı dergiyi tanıma şeklinde gerçekleştiği söylenebilir. Bu model oluşturulurken "Pandemi sürecinden önce kitap fuarına katılıyordum. TÜBİTAK yayımlarını beğenmiştik sonra internet üzerinden araştırınca abone olduk (E2).”; "Arkadaşım tavsiye etmişti ben de marketten arada alıyordum. $\mathrm{O}$ ara indirimi görünce yıllık abone oldum (E5).” kaynak alınmıştır. Katılımcılardan üç tanesi bu soruya cevap vermek istemediği için analize dahil edilmemiştir. 


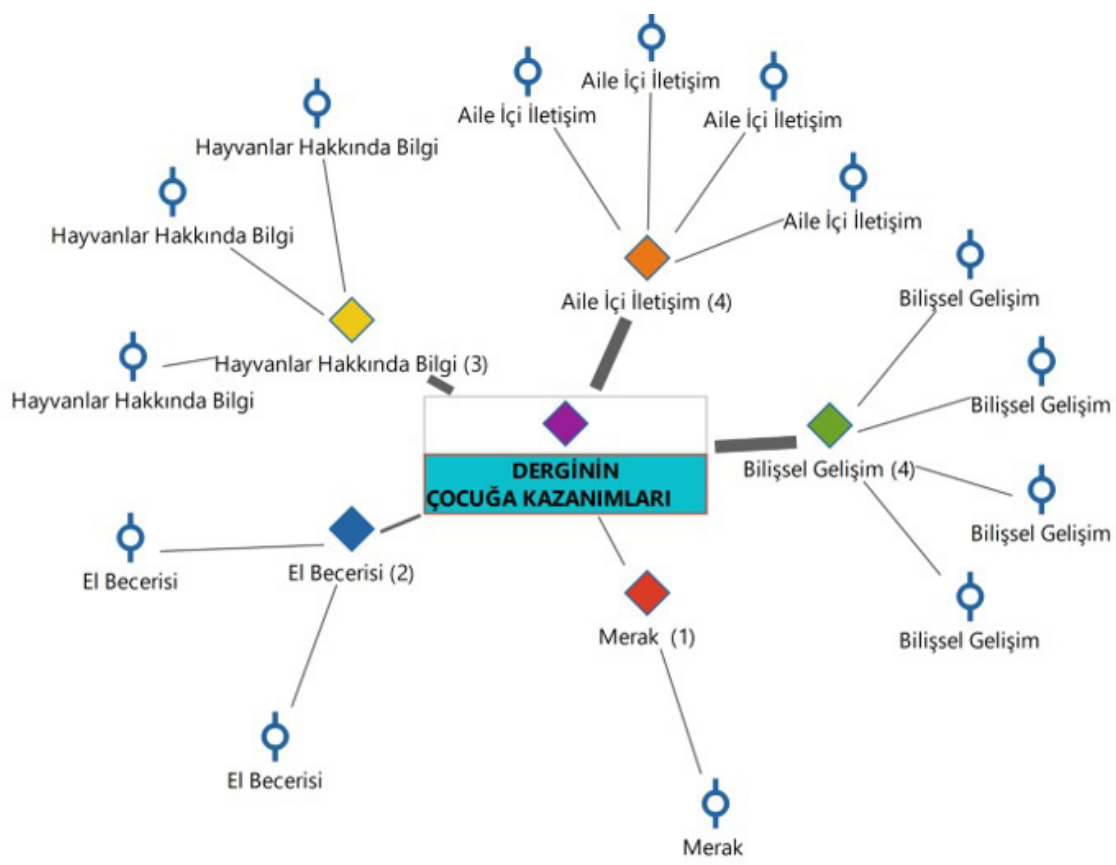

Şekil 3: Meraklı Minik Dergisinin Çocuğa Kazandırdıkları

Şekil 3'te derginin çocuğa kazanımları temasına ilişkin bilişsel gelişimi, aile içi iletişimi, hayvanlar hakkında bilgiler edinmesi, el becerisini geliştirmesi ve merak duygusunun oluşması kategorileri oluşturulmuştur. Bu model oluşturulurken katılımcıların; "Neden sonuç ilişkisi kurabileceği bilimsel verilerin aslında günlük hayatta nasıl düzenlenebileceğine yönelik çok etkinlik var. Oğlumun bunlar içerisinden kendi seviyesine göre yapabildiği ya da yapamadığı etkinlikler oldu. Daha çok canlı resimlerinden, özellikle hayvanlardan çok şey öğrendi. Hayvanları tanıma noktasında çaba içine girdi (E1).”; "Birlikte vakit geçirebiliyoruz. Mutlu oluyor. Okuma isteği oluyor...(E5)”; “...Dergi gelecek diye merakla bekliyor. Dergideki oyunların da zekâ gelişimine katkı sunduğunu düşünüyorum. Aramızdaki iletişim de arttı birlikte vakit geçiriyoruz...(E3)”" cümlelerinden çıkarımlar yapılmıştır. 


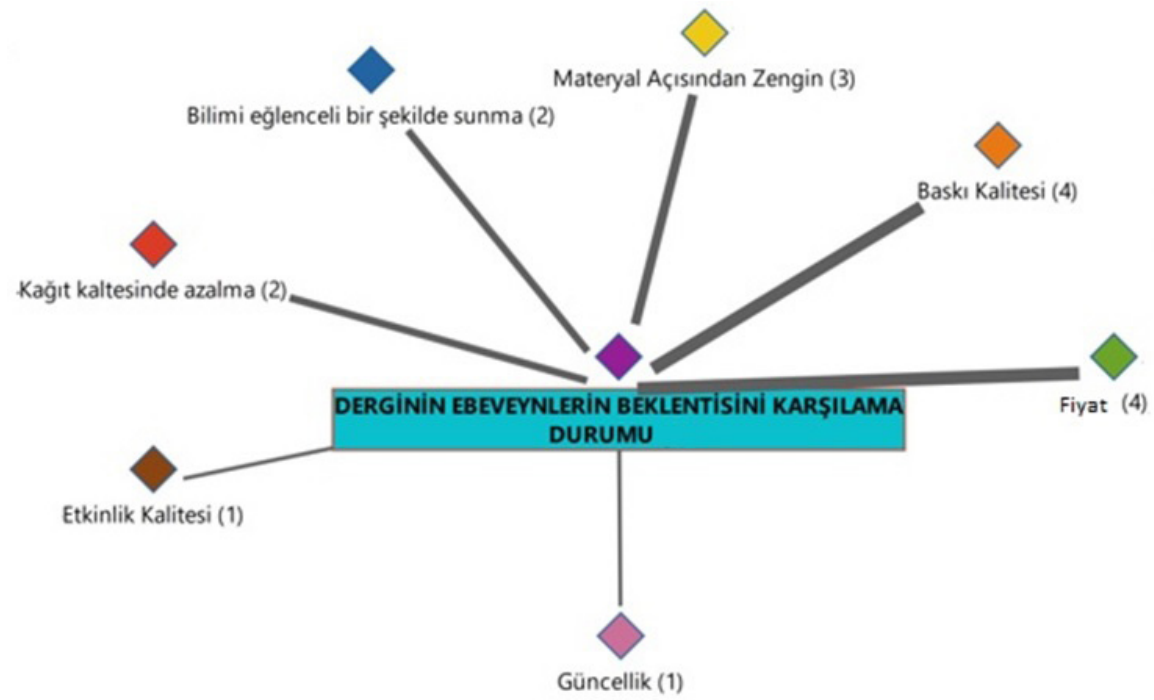

Şekil 4: Meraklı Minik Dergisinin Ebeveynlerin Beklentisini Karşılama Durumu

Şekil 4'de derginin ebeveynlerin beklentilerini karşılama durumu temasına ilişkin "Etkinlik Kalitesi”, "Kâğıt kalitesinde azalma", "Bilimi eğlenceli şekilde sunma", "Materyal açısından zengin olma", "Baskı kalitesi", "Fiyat" ve "Güncellik" biçiminde kategoriler oluşturulmuştur. Fiyat kategorisi, derginin fiyatının pahalı olmamasını ifade etmektedir. “...Etkinlikleri doyurucu. Yanında bir sürü ekleri var... (E2)”; “...İlk aldığım sayılara kıyasla kâğıt kalitesinin değiştiğini düşünüyorum. Ama fiyat olarak herkes alabilir bu yönüyle beklentimi karşılıyor (E4).”; "Son sayılarında kalitede bozulma var. Kâğıt kalitesinde daha çabuk yırtılıyor ama içeriği güncelliyorlar sürekli. Bu yönüyle hala kaliteli (E6).” gibi ifadelerden doğrudan çıkarım yapılarak temalar oluşturulmuştur. 


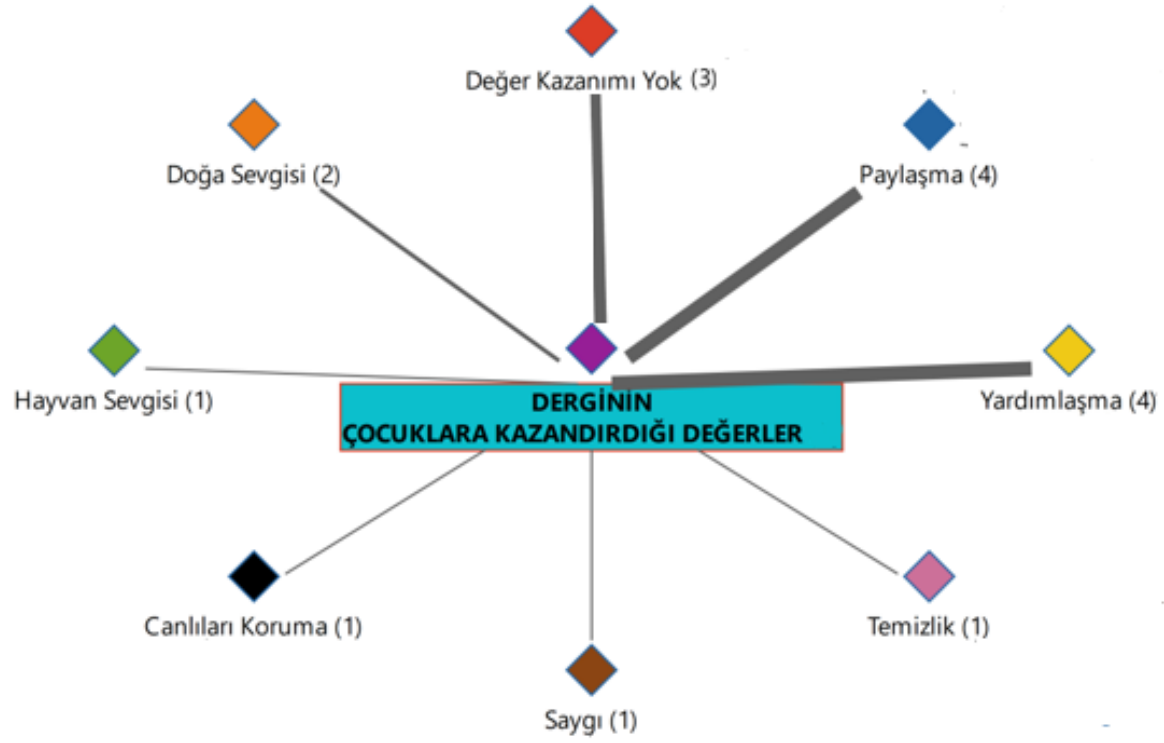

Şekil 5: Derginin Çocuklara Kazandırdığg Değerler

Şekil 5 incelendiğinde derginin çocuklara kazandırdığı değerler temasına yönelik olarak "saygı, canlıları koruma, hayvan sevgisi, doğa sevgisi, paylaşma, yardımlaşma, temizlik, değer kazanımı yok" kategorileri oluşturulmuştur. Bu kategoriler; "En azından burada bitki farkındalığını sağlama, çevre temizliğine yönelik değerleri hissettirme çabası var. Bu benim için önemli. Bu değerleri de işleyerek kazandırdıklarını düşünüyorum (E1).”; "Değer başlıca çocuk demek benim için. Yardımlaşma, kardeş sevgisi, paylaşma gibi değerleri kazandırdığını düşünüyorum (E2).” gibi görüşme sorusuna direk cevaplardan çıkarılmıştır.

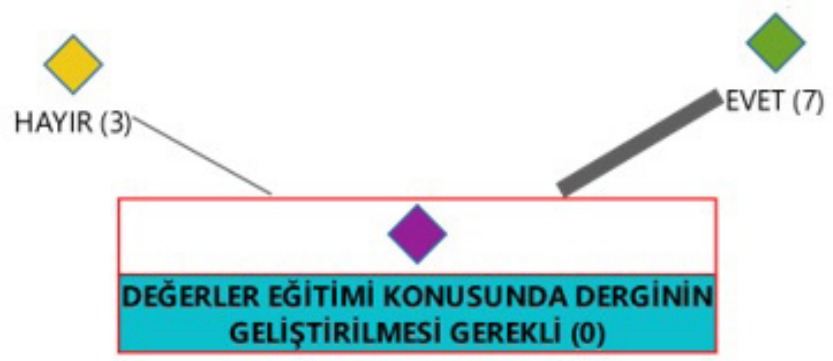

Şekil 6: Derginin Değerler Eğitiminde Geliştirilmesi Durumu

Şekil 6'da derginin değerler eğitimi konusunda geliştirilmesi gerekli temas1na ilişkin "Evet" ve "Hayır" şeklinde iki kategori belirlenmiştir. Üç katılımcının derginin değerler eğitimi konusunda geliştirilmesine gerek olmadığını söylediği görülürken 7 katılımcının derginin değer eğitimi konusunda geliştirilmesi gerekti- 
ğini söylediği sonucuna ulaşılmıştır. Bu kodların oluşturulmasına kaynaklık eden örnek alıntılar; "Derginin çıkış amacında değer yok ama çocukların ilgisini çeken mevzular ve bu yaşlarda kazandırılması gereken ögeler her zaman var. Bilimselliğin içinde dolaylı olarak, dikkat çekici bir şekilde yavaş yavaş değerleri verebilir (E4)."; "Dergi bilimsellik üzerine ama değerler dolaylı olarak veriliyor. Değerlere biraz daha ağılık verilebilir ama çok da ön plana çıkmamalı. Denge iyi korunmalı (E3)."; "Dergide değer ile ilgili direk aklıma gelen bir değer yok. Ama Meraklı Miniğin içerik aşamasında daha çok bilimsel bilginin ya da çocukların günlük hayatta görmüş oldukları bilginin bir yansıması var (E1).” ; "Geçmişimize, kültürümüze yönelik unsurlara daha çok yer verilebilir (E7).” şeklindedir.

\section{Sonuç, Tartışma ve Öneriler}

Meraklı Minik dergisinin 2007 Ocak-2020 Aralı yılları arasında yayımlanan sayılarında en fazla yardımlaşma-dayanışma, bağımsız ve özgür düşünebilme, estetik duyguların geliştirilmesi, sevgi ve sorumluluk değerlerine yer verilmiştir. Benzer şekilde Güler'in (2019) 1970-1983 arasında yayımlanan çocuk dergileri ile 2016-2017 yılları arasında yayımlanan çocuk dergilerinin öğretim programlarına bağlı olarak hangi değerleri ne sıklıkla aktardığını karşılaştırdığı çalışmasında Mavi Kırlangıç, TRT Çocuk, 7'den 70'e Çocuk Dergilerinde "yardımseverlik” değerinin öne çıktığı görülmüsstür. Can ve Günaydı'nın (2019) okul öncesi dönemde oynanan oyunların içerdiği değer unsurlarını ve bunun sınıf yönetimine yansımalarını okul öncesi öğretmenlerinin görüşleri doğrultusunda incelediği çalışmasında öğretmenlerin oyunlarda bulunan değer unsurlarını sırasıyla saygı, sabır, yardımseverlik, sevgi, paylaşma, arkadaşl1k, hoşgörü, empati, işbirliği, özgüven, nezaket, hak-adalet olarak belirttiklerini tespit etmiştir. Gündüz, Aktepe, Uzunoğlu ve Gündüz’ün (2017) okul öncesi dönemdeki çocuklara eğitsel oyunlar yoluyla kazandırılan değerler isimli çalışmalarında; eğitsel oyunlar yoluyla öğrencilere olumlu bağl1lık, yüz yüze etkileşim, iletişim ve sosyal becerilerinin gelişmesi, bireysel sorumluluk gibi değerlerin kazandırıldığı sonucuna ulaşmışlardır. Akıtürk ve Bağçeli-Kahraman'ın (2019) okul öncesi öğretmen adaylarının değerler eğitimine yönelik görüşlerini inceledikleri çalışmalarında okul öncesi öğretmen adaylarının okul öncesi çocuklarına kazandırılabilecek en kolay ilk üç değerin sevgi, saygı ve yardımlaşma olduğunu belirtmişlerdir.

Meraklı Minik dergisinin 2007-2020 yılları arasında yayımlanan sayılarda sırasıyla en az adil olma, alçak gönüllülük, misafirperverlik, nazik olma, fe- 
dakârlık, vatanseverlik değerlerine yer verildiği görülmüştür. Ancak doğruluk, dürüstlük değerlerine hiç yer verilmemiştir. Benzer şekilde Alabay, Can, Kandemir ve Güney'in (2018) TÜBİTAK tarafindan yayımlanan 'Meraklı Minik' dergisinde evrensel değerlere ne düzeyde yer verildiğini belirledikleri çalışmalarında dürüstlük, barış ve alçakgönüllülük değerlerine hiç yer verilmediği görülmüştür. Esmer'in (2007) Cumhuriyet Dönemi'nin ilk y1llarında (1923-1928) yayımlanan çocuk dergilerindeki tahkiyeli metinlerin çocuklara değer aktarımı açısından değerlendirildiği çalışmasında adaletli olmak değerine bir metinde yer verildiği görülmüştür. Güler'in (2019) yaptığı çalışmasında da her iki dönemde incelenen dergilerde milli bayramlar, vatan sevgisi, Atatürk'e önem verme, Cumhuriyet'e önem verme, bayrak sevgisi değerlerinin yeterince işlenmediği belirlenmiştir.

Meraklı Minik Dergisi çocukların; hayvanlar hakkında bilgi edinmesine, el becerisini geliştirmesine, merak duygusunun oluşmasına, bilişsel gelişimine katkı sağlama ve aile içi iletişimi güçlendirme açısından ebeveynlerin beklentilerini karşılamaktadır. Ayrıca derginin; etkinlik kalitesi, sayfa kalitesi, materyal açısından zengin olma, fiyatının ucuzluğu ve güncelliği açısından ebeveynlerin beklentilerini karşılamaktadır. Ancak iki katılımcı derginin son yıllarda kâğıt kalitesinde bozulma olduğunu belirtmiştir. Ağan (2019), Meraklı Minik Dergisini yapısal özellikler açısından değerlendirdiği çalışmasında, kâğıt cinsi ve kalınlığının çocukların gelişim özelliklerine uygun olduğu sonucuna ulaşmıştır. Yıldırım'ın (2020) TÜBİTAK tarafından yayımlanan Meraklı Minik Dergisi'ni Okul Öncesi Eğitim Programı'ndaki kazanımları desteklemesi açısından incelediği çalışmasında derginin en çok dil gelişim alanını ve bilişsel gelişim alanını desteklediğini tespit etmiştir.

Ebeveynlerin çoğuna göre Meraklı Minik Dergisi'nin çocuklara saygı, canlıları koruma, hayvan sevgisi, doğa sevgisi, paylaşma, yardımlaşma, temizlik değerlerini kazandırdığı sonucuna varılmıştır. Esmer'in (2007) çalışmasında öne çıkan hayvan sevgisi ve İdi Tulumcu'nun (2015) 2013 yılında yayımlanan güncel çocuk dergilerinde yer alan değer ifadelerini belirleyip eğitim açısından yorumladığı çalışmasında doğa ve hayvan sevgisi ön plana çıkmıştır. Üç katılımcının derginin bilimsel bir dergi olduğu için dergide herhangi bir değer kazanımı olmadığ1 şeklinde görüş bildirmiştir. Benzer şekilde Meraklı Minik Dergisi'nin amaçları arasında “çocukların araştırma ve keşif gibi bilimsel becerilerini geliştirme" (TÜBİTAK, 2021) yer almaktadır. 
Ebeveynlerin büyük çoğunluğu Meraklı Minik Dergisi'nin değerler eğitimi konusunda geliştirilmesi gerektiğini belirtmiştir. Çok az sayıdaki ebeveyn ise derginin çocukların bilime ilişkin farkındalık kazandırma amacı taşıdığını bu nedenle değerler eğitimine yer vermemesi gerektiğini ifade etmiştir.

Ebeveynlerin Meraklı Minik Dergisi’ne abone olma süreçlerine ilişkin söylemlerine baktığımızda, sırasıyla en çok tavsiye üzerine dergiyi aldıkları, alışveriş yaparken-tesadüfen görüp sonrasında, öğretmenlik mesleğinden dolayı ve kitap fuarında denk gelerek abone olduğu sonucuna ulaşılmıştır. Yıldırım (2020) çalışmasında, TÜBİTAK yayımlarına öğretmenlerin ders içeriklerini oluştururken kaynak ihtiyaçlarını gidermek ve sınıflarında materyal zenginliği sağlamak için abone oldukları sonucuna ulaşmıştır.

Meraklı Minik Dergisi’nin; hedef kitlesi olan okul öncesi dönem çocuklarının özelliklerini dikkate alarak değer kavramlarına daha fazla yer vermesi, dergide sezdirme yolunun dışında belli sayılarda da doğrudan değer temalı bölümlere yer verilmesi, eklerinde aile içi etkinlik ekleri ile değer kavramının daha çok desteklenmesi önerilmektedir. Ayrıca Meraklı Minik Dergisi'nde estetik değer taşıyan çocuk şiirleriyle de değer aktarımı yapılabilir. Meraklı Minik Dergisi'ne TV kanallarında yer verilerek reklamının yapılması ile dergiden haberdar olma durumu artırılabilir. Meraklı Minik Dergisi gibi çocuklar için çıkarılan farklı bilimsel dergilerin de değerler konusunda incelenmesi sağlanabilir. Ülkemizde popüler olan farklı dergilerin değerler eğitimi konusunda bir birleri ile olan ortak yönleri ve farklılıklarına ilişkin bir araştırma yapılabilir.

\section{Kaynakça}

Ağan, S. (2019). "Meraklı Minik" adlı çocuk dergisinin yapısal özellikler açısından değerlendirilmesi. Yüksek lisans tezi, Mersin Üniversitesi.

Akbaş, O. (2008). Değer eğitimi akımlarına genel bir bakış. Değerler Eğitimi Dergisi, 6(16), 9-27. https://dergipark.org.tr/tr/download/article-file/302506

Akman, B., Özen Altınkaynak, Ş., Ertürk Kara, H.G. \& Can Gül, Ş. (2015). Okul öncesi öğretmenlerinin müze eğitimine ilişkin görüşleri. Uludağ Üniversitesi Eğitim Fakültesi Dergisi, 28(1), 97 - 115. https://acikerisim.uludag.edu.tr/ bitstream/11452/12457/1/28_1_5.pdf

Aksüt, P. (2021). TÜBITTAK Yayınlarından Meraklı Minik Dergisinin fen kavramları açısından incelenmesi. Journal of Individual Differences in Education, 3(1), 1-19. DOI: $10.47156 /$ jide. 949588 
Akıtürk, H. K., ve Bağçeli Kahraman, P. (2019). Okul öncesi öğretmen adaylarının değerlereğitimine yönelik görüşleri. Değerler Eğitimi Dergisi , 267-294. https://dergipark.org.tr/tr/download/article-file/894762

Alabaş, R., ve Kamer, T. S. (2016). Afacan çocuk gözü dergisi ve çocuğun vatandaş olarak eğitimi. International Periodical for the Languages, Literature and History of Turkish or Turkic, 11(3), 77-92. DOI: 10.7827/TurkishStudies. 9273

Alabay, E., Can, B. H., Kandemir, A. B., ve Güney, K. (2018). TÜBİTAK tarafindan yayınlanan Meraklı Minik Çocuk Dergisinin değerler açısından incelenmesi. Değerler Ë̆itimi Dergisi , 7-26. https://dergipark.org.tr/tr/download/article-file/514359

Can, E., ve Günaydı, M. (2019). Okul Öncesi Dönemde Çocuk Oyunlarındaki Değer Unsurları: Sınıf Yönetimine Yansımaları . Insan ve Toplum Bilimleri Araştırması Dergisi , 2147-1185. DOI: 10.15869/itobiad.615618

Chapman, K. J., Fairchild, R. M., \& Morgan, M. Z. (2014). Food references in UK children's magazines an oral health perspective. British dental journal, 217(10), DOI: 10.1038/sj.bdj.2014.1007

Cooper, D. (2014). Character education: A study of an elementary school leadership Academy (Yayımlanmamış doktora tezi). Wilmington University, USA

Dedeoğlu, H., Şahin, A. E., Ulusoy, M., \& Ertem, İ. S. (2011). Çocuk dergileri üzerine bir içerik analizi: Bilim Çocuk ve National Geographic Kids. Akdeniz Eğitim Araştırmaları Dergisi, 9, 27-38. https://www.acarindex.com/pdfler/ acarindex-4a49af97-8050.pdf

Duran, E., ve Dolaylar Özkul, İ. (2018). Türk çocuk dergileri ile ilgili öğrenci görüşlerinin belirlenmesi. Journal of History Culture and Art Research, 7(1), 467-478. DOI: 10.7596/taksad.v7i1.1362

Ergin, G. (2020). Okul öncesi (48-60 ay) dönem çocuklarında Tübitak’ın Meraklı Minik Dergisi'ndeki etkinliklerin sosyal beceri ve bilişsel tempo düzeylerine etkisinin incelenmesi. Yüksek lisans tezi, Dumlupınar Üniversitesi.

Ergin, G., ve Özkan, B. (2021). Examining the effect of Merakli Minik activities on preschool children's social skills. Southeast Asia Early Childhood Journal, 10(1), 28-36. DOI: 10.37134/saecj.vol10.1.3.2021

Esmer, S. K. (2007). Cumhuriyet döneminin ilk yıllarında (1923 - 1928) yayımlanan çocuk dergilerindeki tahkiyeli metinlerin çocuklara değer aktarımı açısından değerlendirilmesi. Yüksek lisans tezi, Gazi Üniversitesi.

Gezmen, B. (2019). Bir eğitim aracı olarak çocuk dergileri: "Mavi kırlangıç çocuk dergisi”. Erciyes İletişim Dergisi, 1, 59-80. DOI: 10.17680/erciyesiletisim.466195 
Güler, B. (2019). Çocuk dergilerinde değerler aktarımının ilköğretim programları ile ilişkilendirilmesi üzerine bir araştırma. Yüksek lisans tezi, Niğde Ömer Halis Demir Üniversitesi.

Gündüz, M., Aktepe, V., Uzunoğlu, H., ve Gündüz, D. D. (2017). Okul öncesi dönemdeki çocuklara eğitsel oyunlar yoluyla kazandırılan değerler. $M S K U$ Eğitim Fakültesi Dergisi , 62-70. DOI: 10.21666/muefd.303856

İdi Tulumcu, F. (2015). Güncel çocuk dergilerinde yer alan değerler. Yüksek lisans tezi, Sakarya Üniversitesii

Jones, S., ve Reid, A. (2009). Children's magazines: reading resources or food marketing tools? Public Health Nutrition, 13(3), 393-399. DOI: 10.1017/ S1368980009991133

Karademir, A., ve Çelik, İ. (2020). Okul öncesi öğretmenleri bakış açısılla millî değerlerimiz: Türk büyükleriyle ahlak eğitimi. Değerler Eğitimi Dergisi,18 (40), s.277-306. DOI: 10.34234/ded.762815

Kalaycı, N., Güneş, E. (2014). Resmi programdaki örtük mesajların öğrencilerin özgürlük değerine ilişkin algıları üzerindeki etkisinin belirlenmesi. Türk Eğitim Bilim Dergisi 12(1), 17-34. https://dergipark.org.tr/tr/download/article-file/256147

Karasar, N. (2013). Bilimsel Araştırma Yöntemi. Nobel Yayıncılık.

Kurniawan, H., Waluyo, J. H., Suwandi, S. ve Setiawan, S. (2018). Moral value in archipelago 1slamic perspective in children's stories in "bobo" magazine and "kompas" daily. Jurnal Kaijan Islam dan Budaya,16(2) 224-245. DOI: 10.24090/ibda.v16i2.1804

MEB. (Milli Eğitim Bakanlığı) (2010). İlk Ders Genelgesi 2010/53. http://mebk12. meb.gov.tr/meb_iys_dosyalar/34/39/749197/dosyalar/2015_02/09093609_ degerleregitimi.pdf

Meriç, A. ve Özyürek, A. (2018). Okul öncesi dönem çocukların ahlaki ve sosyal kural bilgilerinin incelenmesi. OPUS - Uluslararası Toplum Araştırmaları Dergisi, 8(14), 137-166. DOI: 10.26466/opus.378956

Morrow, L., ve Lesnick, J. (2001). Examining the educational value of children's magazines. The California Reader, 34(2), 2-13.

Neuman, W. L. (2014). Social research methods: Qualitative and quantitive approaches (7th Edition). Essex, Pearson Education Limited.

Sagiv, L. (2002). Vocational interests and basic values. Journal Career Assess. 10(2), 233-257. DOI: 10.1177/1069072702010002007

Sarıkaya, M. (2018). Türkiye Cumhuriyeti’nin ilk yıllarında yayınlanan çocuk dergilerindeki “akıl oyunları” örnekleri. Munzur Üniversitesi Sosyal Bilimler 
Dergisi, 7(13), 9-28. https://dergipark.org.tr/tr/download/article-file/61589

Selçuk, Z., Palancı, M., Kandemir, M. ve Dündar, H. (2014). Eğitim ve bilim dergisinde yayınlanan araştırmaların eğilimleri: içerik analizi. Eğitim ve Bilim, 39 (173), 430-453. http://egitimvebilim.ted.org.tr/index.php/EB/article/view/3278/720

Silcock, P. ve Duncan, D. (2001). Values acquisition and values education: Some proposals. British Journal of Educational Studies, 49(3), 242-259. DOI: 10.1111/1467-8527.t01-1-00174

Stake, R. E. (1995). The art of case study research. Thousand Oaks, Sage Publications

Pembegül, B. N. (2019). TÜBİTAK Tarafindan Çocuklara Yönelik Yayımlanan Popüler Bilim Dergilerinin Çocuk Hakları Açısından Incelenmesi. Yüksek lisans tezi. Hacettepe Üniversitesi.

Rea, L. (2018). Education, popular literature and future citizenship in argentina's billiken children's magazine (1919-1945). Global studies of childhood, 8(3), 281-291. DOI: 10.1177/2043610618797403

Tekinşen, A. B. (2019). TRT Çocuk Dergisi'nde yer alan edebî metinlerin değerler eğitimi açısından incelenmesi. Yüksek lisans tezi. Gaziantep Üniversitesi.

TÜBİTAK. (2021). Meraklı Minik Dergisi. https://merakliminik.tubitak.gov.tr/sayfa/bizi-taniyin

Yılar, Ö., ve Celepoğlu, A. (2007). Çocuk yayınları ve bu yayınlarda bulunması gereken temel unsurlar. Ö. Yıllar ve L. Turan (Ed.), Çocuk edebiyatı. PEGEM Akademi.

Yıldırım, A., ve Şimşek, H. (2013). Sosyal bilimlerde nitel araştırma yöntemleri. Seçkin Yayıncılık.

Yıldırım, M. (2020). Tübitak Meraklı Minik Dergisi’nin içeriğinin MEB okul öncesi eğitim programındaki kazanımlar açısından incelenmesi. Yüksek lisans tezi. Gazi Üniversitesi.

Yılmaz, M. (2018). TRT Çocuk Dergisi’nde Milli Değerler. Yüksek Lisans Tezi, Gazi Üniversitesi.

Yiğitbaşı, G. K. (2014). Türkiye'de çocuk dergiciliği: TRT Çocuk Dergisi örneği. Iğdır Üniversitesi Sosyal Bilimler Dergisi, 5, 37-56. http://sosbilder.igdir. edu.tr/Makaleler/1246021811_04_Guran_(37-56).pdf

Yurtseven, N. (2019). Öğretimi planlama ve uygulama sürecinde örtük programın rolüne ilişkin öğretmen görüşlerinin incelenmesi. Ulusal Eğitim Akademisi Dergisi (UEAD), 3(1), 62-83. DOI: 10.32960/uead.513425 
Extended Abstract

\section{The Evaluation of the "Meraklı Minik" Magazine for Preschool Children in Terms of Values Education}

Ensar YILDIZ, Corresponding Author, Research Assistant.

Sivas Cumhuriyet University, Faculty of Education, Sivas / Turkey ensaryildiz@outlook.com.tr

https://orcid.org/0000-0003-3741-1121

Kübra EMIN, Master Degree Student

Sivas Cumhuriyet University, Faculty of Education, Sivas / Turkey

kubragemin@gmail.com

https://orcid.org/0000-0002-4852-8459

Şuheda BAYRAK, Master Degree Student

Sivas Cumhuriyet University, Faculty of Education, Sivas / Turkey suheda2011@gmail.com

https://orcid.org/0000-0002-0068-3871

Büşra YIKILMAZ BARAN, Master Degree Student Sivas Cumhuriyet University, Faculty of Education, Sivas / Turkey busrayikilmaz1@gmail.com https://orcid.org/0000-0003-3762-985X

Article Type: Research Article

https://doi.org/10.34234/ded.816307

Received Date: 07.05 .2020

Accepted Date: 27.09 .2021

Published Date: 25.12 .2021 


\section{Introduction}

Before starting formal education, children learn social rules and values and to distinguish right from wrong by observing and imitating their parents (Meriç and Özyürek, 2018). Given that the family is the first social institution where value education first takes place, parents have a great responsibility. Besides being a role model for children, the environment and resources provided by families are also important in values education (Y1lmaz, 2018). One of these resources is considered to be children's magazines that seen to be an educational tool to transfer values to children (Tekinşen, 2019).

Children's magazines are periodicals that aim to make children internalize the reading habit in an enjoyable way, and to inform children about scientific developments, values and daily life skills (Duran and Dolaylar Özkul 2018). In January 2007, TÜBITAK started publishing the magazine "Meraklı Minik" for 3-6-year-old children that aimed to endear science to children and to develop their sense of curiosity, and it is still being published (Dedeoğlu, Ertem, and Şahin, 2011). It can be stated that studies on values education in preschool children's magazines have not reached the desired level (Tekinşen, 2019). Drawing attention to values education by examining the values in a magazine that aim to make children love science is of great importance in terms of increasing the importance of values education. In this current study, it is aimed to evaluate "Meraklı Minik" Magazine in terms of values education and parental views. To this end, answers were sought to the following questions:

1. Which values are included in "Meraklı Minik" Magazine at which frequencies?

2. Does "Merakl1 Minik" Magazine meet the expectations of parents?

3. According to parents, which values are transferred to children by "Merakl1 Minik" Magazine?

4. What are the suggestions of parents for improving "Meraklı Minik" Magazine in terms of values education?

\section{Method}

Criterion sampling, one of the purposeful sampling methods, was used in the selection of the sample of the study, which was carried out in accordance with the qualitative paradigm. The criteria adopted in the selection of the participants 
of the second study group are being a parent to at least a child aged between 3-6 and having at least 6 month-subscription to "Meraklı Minik" magazine. The study made use of two different types of data sources. The data are consisted of 156 issues of the "Merakl1 Minik" magazine between 2007-2020 and views of 10 parents of preschool children. As a data collection tool, document analysis was used by The Value Classification Form" developed by the researchers using The Circular Letter numbered 53 issued in 2010 by the Ministry of National Education and the semi-structured interview form developed by the researchers to reveal parents' views.

Content analysis, one of the qualitative data analysis methods, was used in the analysis of the data obtained in the study. The main purpose in content analysis is to reach concepts and relationships in order to explain the collected data (Selçuk, Palanc1, Kandemir and Dündar, 2014). The main thing done with content analysis is to classify similar data into groups and themes in such a way to be accurately understood by the reader (Yıldırım and Şimşek, 2013). The coding categories related to the values made up from the monthly issues of "Merakl1 Minik" Magazine published between 2007 and 2020 were analyzed.

In the second stage of the study, interviews that were transcribed were modelled with the MAXQDA program. Codes, categories and themes were created by the researchers. Twenty percent of the transcriptions were sent to an independent researcher who had experience in qualitative research and the expert was asked to analyze the data. The codes, categories and themes created by the researcher and the expert were found to be compatible with each other.

\section{Findings}

A total of 26 values were addressed in the issues of "Merakl1 Minik" Magazine published between 2007 and 2020. While the most frequently emphasized values in these issues are helpfulness and solidarity (N: 417) and developing aesthetic feelings ( $\mathrm{N}: 325)$, the least frequently emphasized ones are being fair $(\mathrm{N}: 1)$, modesty $(\mathrm{N}: 7)$, hospitality $(\mathrm{N}: 7)$, kindness (10), altruism $(\mathrm{N}: 10)$ and patriotism (N: 11). It is seen that family values were addressed only in 2015 and the value of modesty in 2010 and 2011, while the values of integrity and honesty were not mentioned in the issues that included from 2007 the year of its first publication until 2020. On the other hand, it has been determined that the values of independent and free thinking, the development of aesthetic feelings, love and cleanliness have been emphasized every year. It was observed that 
while the greatest emphasis was put on values in the issues published in 2020 (N: 210), whereas the least emphasis was put on values in the issues published in 2015 (N: 84).

In the interviews conducted with the parents, the categories of cognitive development, familial communication, acquiring information about animals, developing handicraft and developing a sense of curiosity were formed regarding the theme of the gains to be acquired by the child through "Merakl1 Minik" Magazine.

Regarding the theme of the journal's meeting the expectations of parents, categories such as "Activity quality", "Decrease in paper quality", "Presenting science in an entertaining way", "Richness in material", "Print quality", "Price" and "Up-to-dateness" were created.

\section{Discussion, Conclusions and Suggestions}

In the issues of "Merakl1 Minik" Magazine published between 2007 and 2020, the values of helpfulness-solidarity, independent and free thinking, development of aesthetic feelings, love and responsibility were the most emphasized values. Similarly, Güler (2019) compared children's magazines published between 1970 and 1983 and children's magazines published between 2016 and 2017 in terms of which values were addressed at which frequency in relation to values stated in curriculums and found that the value of "benevolence" came to the fore in children's magazines; "Mavi Kırlangıç", "TRT Çocuk" and "7'den 70'e".

In the issues published by "Meraklı Minik" Magazine between 2007 and 2020, the least frequently emphasized values were found to be being fair, modesty, hospitality, kindness, altruism, patriotism. However, no place was allocated to the values of integrity and honesty. Similarly, Alabay, Can, Kandemir and Güney (2018) found that the values of honesty, peace and modesty were not included in "Meraklı Minik" Magazine published by TÜBİTAK in a study they conducted to determine the extent to which universal values were included in the magazine. In the study of Esmer (2007) evaluating the narrative texts in children's magazines published in the first years of the Republic Period (19231928) in terms of transferring values to children, it was seen that the value of being fair was included in texts.

The findings would suggest that, in certain issues of "Meraklı Minik" Magazine, sections directly focused on the theme of value can be included, and the 
concept of value can be further supported with family activity supplements of the magazine. In "Meraklı Minik" Magazine, values can be transferred with children's poems that have aesthetic values. Raising awareness about the magazine can be increased by placing advertisements related to "Meraklı Minik" Magazine on TV channels. Different scientific journals published for children, similar to "Meraklı Minik" Magazine, can also be promoted for the examination of values.

Etik Beyan / Ethical Statement: Bu çalışmanın hazırlanma sürecinde bilimsel ve etik ilkelere uyulduğu ve yararlanılan tüm çalışmaların kaynakçada belirtildiği beyan olunur. / It is declared that scientific and ethical principles have been followed while carrying out and writing this study and that all the sources used have been properly cited.

Finansman / Funding: Yazarlar, bu araştırmayı desteklemek için herhangi bir dış fon almadıklarını kabul ederler. / The authors acknowledge that they recevied no external funding in support of this research.

Yazar (lar) / Author (s): Ensar YILDIZ, Kübra EMIN, Şuheda BAYRAK, Büşra YIKILMAZ BARAN

Yazar Katkıları / Author Contributions: Ensar YILDIZ (\%25), Kübra EMIN (\%25), Şuheda BAYRAK (\%25), Büşra YIKILMAZ BARAN (\%25)

Çıkar Çatışması / Competing Interests: Yazarlar, çıkar çatışması olmadığını beyan ederler. / The authors declare that they have no competing interests. 